\title{
GOODREADS I SAVJETOVANJE ČITATELJA NA PRIMJERU KORISNIKA IZ HRVATSKE
}

\author{
GOODREADS AND READERS' ADVISORY \\ ON THE EXAMPLE OF CROATIAN USERS
}

\author{
Mirko Duić \\ Odjel za informacijske znanosti \\ Sveučilište u Zadru \\ miduic@unizd.hr \\ Maja Mrgić \\ Osnovna škola "Vladimir Nazor" Neviđane \\ os-nevidane-knjiznica@zd.t-com.hr
}

UDK / UDC 004.775:028.8(497.5)

Izvorni znanstveni rad / Original scientific paper

Primljeno / Received:16. 8. 2019.

Prihvaćeno / Accepted: 22. 10. 2019.

\section{Sažetak ${ }^{1}$}

Cilj / Svrha. Goodreads je popularni mrežni portal i društvena mreža fokusirana na knjige i čitanje. Cilj je rada istražiti upotrebu Goodreadsa od strane korisnika iz Hrvatske s fokusom na aktivnosti savjetovanja čitatelja: pisanje i čitanje prikaza knjiga te preporuka za čitanje. Također, cilj je bio utvrditi koje sve izraze korisnici upotrebljavaju u svojim prikazima knjiga na Goodreadsu nastojeći opisati različite vidove privlačnosti knjige. Svrha je rada upoznati stručnu zajednicu s mogućnostima korištenja podataka s portala Goodreads u knjižničnim aktivnostima (savjetovanje čitatelja, izrada kataloga). Također, svrha je rada predstaviti literaturu vezanu uz Goodreads i savjetovanje čitatelja, kao i predstaviti pojam privlačnosti knjige.

Metodologija. U radu su korištene metode online ankete i sadržajne analize prikaza knjiga čiji su autori korisnici Goodreadsa iz Hrvatske. Za provedbu sadržajne analize korištena je taksonomija vezana uz pet vidova privlačnosti autorice J. Saricks.

1 Rad je nastao na temelju diplomskog rada studentice Maje Mrgić, napisana pod naslovom Goodreads i savjetovanje čitatelja na primjeru korisnika iz Hrvatske i nastala pod mentorskim vodstvom Mirka Duića. Rad je obranjen na Sveučilištu u Zadru 2019. godine.

Vjesnik bibliotekara Hrvatske 62, 2(2019), 33-64

ISSN 0507-1925 
Rezultati. Rezultati provedenog istraživanja ukazuju na to da većina ispitanika piše prikaze knjiga koje su pročitali, da gotovo pedeset posto ispitanika dodaje i preporuke za čitanje te da je gotovo svatko od ispitanika barem jednom odabrao knjigu za čitanje na temelju preporuke kojeg drugog korisnika Goodreadsa. Sadržajnom pak analizom prikazanih knjiga utvrđeno je da autori prikaza koriste razne izraze za opis pet vidova privlačnosti knjige.

Originalnost/vrijednost. $U$ radu je predstavljena tema koja do sada nije bila zastupljena u domaćoj literaturi, dodatno obogaćena rezultatima provedena istraživanja. Ukazuje se na različite aktivnosti korisnika portala Goodreads, čije bi proučavanje moglo unaprijediti poslovanje knjižnica, a posebno aktivnost savjetovanja čitatelja.

Ključne riječi: društveno čitanje, Goodreads, privlačnost knjige, savjetovanje čitatelja

\section{Abstract}

Aim / Purpose. Goodreads is a popular web portal and a social network focused on books and reading. The aim of this paper is to explore the use of Goodreads by the users from Croatia, focusing especially on their readers' advisory activities: writing and reading book reviews, as well as book recommendations. Furthermore, the aim is to find out which terms the users use in their book reviews published on Goodreads when describing various aspects of book appeal. The purpose of the paper is to acquaint the professional community with the possibilities of the use of data from the portal Goodreads in library activities (readers' advisory, catalog creation, etc.). Also, the purpose is to present the literature related to Goodreads and readers' advisory, as well as to present the concept of book appeal.

Methodology. Methods used in the research were: online survey and content analysis of book reviews written by the Goodreads users from Croatia. The content analysis was based on the taxonomy related to five aspects of the book appeal described by $\mathrm{J}$. Saricks.

Findings. The research findings indicate that the majority of the survey participants write reviews of books which they have read, that in these reviews almost half of the participants are adding book recommendations, and that almost all the participants sometimes choose a book to read based on the recommendations of other Goodreads users. Through the content analysis it was established that the authors of the reviews use different terms for describing five aspects of the book appeal.

Originality/value. The paper presents the topic which has not been presented in the domestic literature, and it is additionally enriched with the research results. Various activities of the Goodreads portal users are pointed out, particularly those whose study could improve the library activities, especially the readers' advisory activity.

Keywords: book appeal, Goodreads, readers' advisory, social reading 


\section{Uvod}

Portali o knjigama i čitateljske društvene mreže na internetu, poput Goodreadsa ili LibraryThinga, namijenjeni su korisnicima sa svrhom informiranja o knjigama i omogućivanja međusobnog komuniciranja te dijeljenja informacija vezanih uz knjige i čitanje. U ovome radu istražili smo određene aspekte korištenja portala i čitateljske društvene mreže Goodreads koja je pokrenuta u siječnju 2007. godine, da bi ubrzo stekla globalnu popularnost među čitateljima. Ne iznenađuje stoga da se 2013. godine poduzeće Amazon odlučilo kupiti Goodreads. ${ }^{2}$ U kolovozu 2019. godine taj portal i društvena mreža ima čak 90 milijuna korisnika, 2.6 milijarde opisanih knjiga i 90 milijuna recenzija, tj. prikaza knjiga. ${ }^{3}$ Aktivnosti korisnika Goodreadsa nerijetko se znanstveno istražuju zbog različitih zanimljivih fenomena koji su se pojavili. Jedan je od tih fenomena i to da čitatelji, članovi Goodread$s a$, preuzimaju ulogu savjetovanja drugih čitatelja te pružaju preporuke o tome vrijedi li neku knjigu čitati ili ne. Savjetovanje čitatelja (engl. readers' advisory) aktivnost je koja već dugo postoji u knjižničarstvu, a odnosi se na sve metode korištene za približavanje knjižnične građe korisnicima. ${ }^{4}$ Prije pojave internetskih alata takve savjete čitatelji su mogli dobiti uglavnom prilikom posjete knjižnicama, izravno od obučenih knjižničara. U ovom se radu nastojalo saznati na koji način sami čitatelji postaju pružatelji takvih savjetodavnih usluga usmjeravajući se prema drugim korisnicima portala Goodreads. U radu se također nastoje utvrditi i kategorizirati izrazi za opis privlačnosti knjige koje korisnici Goodreadsa najčešće koriste u svojim prikazima pročitanih knjiga. Izrazi privlačnosti analizirani su prema kategorijama privlačnosti knjige koje je predložila Joyce Saricks u svojoj knjizi Usluga savjetovanja čitatelja u narodnoj knjižnici. ${ }^{5}$

\section{Savjetovanje čitatelja u digitalnom dobu}

Savjetovanje čitatelja (engl. Readers'Advisory), prema Saricks, uključuje „približavanje građe čitateljima i korisnicima knjižnice putem neizravnih i izravnih metoda“. ${ }^{6}$ To znači da se knjižnična građa čitateljima predstavlja u razgovoru, putem popisa prijedloga, posebno izdvojenih izloga građe i slično. Savjetovanje

\footnotetext{
2 Usp. Amazon purchase of Goodreads stuns book industry. [citirano: 2019-8-11]. Dostupno na: https:/www.theguardian.com/books/2013/apr/02/amazon-purchase-goodreads-stuns-book-industry.

3 Usp. Goodreads.About us. [citirano: 2018-8-11]. Dostupno na: https://www.goodreads.com/ about/us.

4 Usp. Anwyll, R.; B. Chawner. Social media and readers' advisory: a win-win combination? // Reference \& User Services Quarterly 53, 1(2013), str.18. [citirano: 2019-10-21]. Dostupno na: https://go.galegroup.com/ps/anonymous?id=GALE\%7CA351948534.

5 Usp. Saricks, J. G. Readers' advisory service in the public library. Chicago: American Library Association, 2005.

6 Isto, str. 18.
} 
čitatelja obično se shvaća kao jedna od najvažnijih knjižničnih usluga. J. Moyer uslugu savjetovanja čitatelja smatra temeljnom knjižničarskom praksom jer se u toj aktivnosti povezuju tri temeljna elementa: interesi korisnika knjižnice, ukupnost knjižnične zbirke i vještine knjižničara. ${ }^{7}$ Tvrdi da je snažan program savjetovanja čitatelja bitan kako bi se podržalo čitateljske interese korisnika. Također, savjetovanje čitatelja motivira korisnike da nastave koristiti knjižnicu. ${ }^{8}$

Prema Vijeću za savjetovanje čitatelja koje djeluje u sklopu Američkog knjižničarskog društva $a^{9}$, ključan element koji pridonosi tomu da knjižničari pružaju kvalitetnu uslugu savjetovanja čitatelja jest njihovo obrazovanje za rad s čitateljima i razumijevanje različitih aspekata knjige koji ju čine privlačnom čitatelju. Drugi ključan element jest to da su knjižničari upoznati s izvorima informacija uz pomoć kojih mogu povezati čitatelja i knjigu. ${ }^{10} \mathrm{Ti}$ su elementi potrebni kako bi se postiglo da knjižničari budu dostatno informirani i sposobni čitatelju ponuditi kvalitetnu uslugu savjetovanja. U skladu s tim je i ideja, koju iznosi Saricks, da je neodvojiva sastavnica dobrog savjetovanja čitatelja knjižnično osoblje koje posjeduje potrebna znanja te opremljenost knjižnice građom koja odgovara zahtjevima korisnika. ${ }^{11}$ Saricks primjećuje da je za pružanje kvalitetne usluge savjetovanja u knjižnici vrlo važna posvećenost knjižničara ideji zadovoljavanja čitateljskih interesa korisnika. Nadalje, važno je i to da su knjižničari spremni uložiti trud u savjetovanje bez obzira na čitateljske interese čitatelja. ${ }^{12}$ Osim dobrog poznavanja građe, Saricks smatra da su najvažnije osobine knjižničara želja da uspostavi vezu između čitatelja i knjige, interes za čitanje tematski različitih knjiga, poznavanje interesa korisnika, popularnih knjiških naslova i žanrova te autora. ${ }^{13}$ Važan su izvor tih znanja i sami korisnici. Knjižničari od čitatelja dobivaju vrijedne informacije o knjigama, ali i o samim čitateljima, stoga svakom razgovoru trebaju pristupiti s velikom pozornošću. ${ }^{14}$

J. A. Cordón-García i suradnici u svojoj knjizi Društveno čitanje prikazuju čitanje kao društvenu djelatnost, u smislu da se dijelom čitalačkog procesa smatra i

\footnotetext{
7 Usp. Moyer, J. Research-based readers' advisory. Chicago: American Library Association, 2008. Str. 259.

8 Usp. isto, str. 5

9 Vijeće za savjetovanje čitatelja dio je Odsjeka za razvoj i vrednovanje zbirke (Collection development and evaluation section / CODES) koji je dio Američkog knjižničarskog društva (American library association).

10 Usp. Collection development and evaluation section (CODES) Readers' advisory committee. Recommended readers' advisory tools. // Reference \& User Services Quarterly 43, 4(2004), str. 294. [citirano: 2019-10-21]. Dostupno na: https://www.jstor.org/stable/20864241.

11 Usp. Saricks, J. G. Nav. dj., str. 2.

12 Usp. isto, str. 11.

13 Usp. isto, str. 11.

14 Usp. isto, str. 37.
} 
potreba čitatelja da s okolinom dijeli svoje dojmove i razmišljanja o pročitanom. ${ }^{15}$ Knjižničari tu potrebu odavno uključuju u svoj rad organizirajući razgovore o knjigama, pružajući prostor i podršku za razmjenu mišljenja o pročitanom. Međutim ta podrška u današnjem svijetu ne mora više biti vezana uz čitateljima blizak prostor, već se komunikacija može odvijati internetom, među čitateljima diljem svijeta. Pojavom novih medija mijenja se i mreža ljudi s kojima čitatelji razmjenjuju razmišljanja. Ljude sa sličnim čitateljskim i drugim stavovima u takvom je okruženju puno lakše pronaći i komunicirati s njima. ${ }^{16}$ Mnogi čitatelji žele razgovarati o knjigama, a S. K. Burke i M. Strothmann smatraju da priličan broj njih takve razgovore želi voditi na internetu. ${ }^{17} \mathrm{~B}$. Trott smatra da se povećava vjerojatnost da će čitatelji tražiti pomoć u izboru knjige, ako ju je moguće pružiti bez fizičkog susreta knjižničara i čitatelja. ${ }^{18} \mathrm{Ne}$ čudi stoga pojava internetskih portala i 'alata' poput Facebooka, Twittera, Goodreadsa, popisa knjiga i baza podataka koji mogu pomoći čitateljima u odabiru knjiga. Moyer smatra da su ti portali i alati omogućili da savjetovanje čitatelja postane profesionalna usluga. Oni proširuju mogućnosti savjetovanja, koje više nije ograničeno čitalačkim interesima samih knjižničara. ${ }^{19}$ Prema tome, poželjno je da knjižničari prate i mrežne izvore kako bi mogli bolje informirati korisnike. Knjižničari se mogu koristiti tim izvorima da se bolje informiraju o tome što čitatelji čitaju ili kako razgovaraju o knjigama. Dostupne mrežne izvore mogu predložiti korisnicima kao pomoć u odabiru knjiga za čitanje.

Važan poticaj knjižnicama da u svoj rad uključe mrežne tehnologije leži u činjenici da se sve više korisnika oslanja na internet kako bi se informirali o knjigama, dok je prije ta usluga češće pripadala domeni knjižničara informatora. Saricks ukazuje na još jednu novu pojavu: kada knjižničari uoče da dolazi do smanjenja posudbi knjiga i informacijskih upita, potrebno je razmotriti nove načine predstavljanja usluga koje nude. ${ }^{20}$ Cordón-García i suradnici u uspostavi mrežne usluge savjetovanja čitatelja vide dvostruku ulogu: jedna se tiče savjetovanja čitatelja, dok se druga odnosi na približavanje knjižnične građe. ${ }^{21}$ Stover je savjetovanje čitatelja proglasila najdruštvenijom uslugom knjižnica. Stoga ju ne čudi što su

15 Usp. Cordón-García, J. A.; J.Alonso-Arévalo; R. Gómez-Díaz; D. Linder. Social reading: platforms, applications, clouds and tags. Cambridge: Woodhead Publishing Limited, 2013. Str. 2.

16 Usp. isto, str. 78.

17 Usp. Burke, S. K.; M. Strothmann. Adult readers' advisory services through public library websites. // Reference \& User Services Quarterly 55, 2(2015), str. 142. [citirano: 2019-10-21]. Dostupno na: https://journals.ala.org/index.php/rusq/article/view/5861.

18 Usp. Trott, B. Advising readers online: A look at internet-based reading recommendation services. // Reference \& User Services Quarterly 44, 3(2005), str. 212. [citirano: 2019-10-21]. Dostupno na: https://www.jstor.org/stable/20864364.

19 Usp. Moyer, J. Nav. dj., str. 179.

20 Usp. Saricks, Joyce. Nav. dj., str. 2.

${ }^{21}$ Usp. Burke, S. K.; M. Strothmann. Nav. dj., str. 133. 
se razgovori o knjigama brzo preselili na internet kao novi prostor na kojemu se odvija komunikacija čitatelja. ${ }^{22}$

Prema Trottu postoji aktivno i pasivno savjetovanje čitatelja. Pasivno savjetovanje uključuje popise knjiga prema temi, žanru ili autoru, uključuje programe usmjerene na čitanje, kao i druge aktivnosti kojima je namjena pomoći čitateljima koji traže nove naslove za čitanje. Aktivno je savjetovanje ono kojemu knjižnice trebaju težiti i koje od knjižničara zahtijeva više napora jer moraju uložiti znatan trud u cilju promicanja usluge savjetovanja. ${ }^{23}$

No uz savjetovanja čitatelja koja pružaju knjižničari, postoje i mnogi mrežni portali koji služe istoj svrsi, a nisu vezani uz knjižnicu. Važno je da se knjižničari upoznaju s tim portalima, među kojima za potrebe ovoga rada posebno ističemo Goodreads i LibraryThing. Knjižničari pomoću tih portala mogu pratiti trendove u izdavaštvu i čitalačkim navikama i interesima. Osim toga, ti portali omogućuju knjižničarima komunikaciju s korisnicima knjižnice na nov način. Omogućuju knjižničarima da dopru do korisnika koji ne dolaze često u knjižnicu ili ju uopće ne koriste. ${ }^{24}$ Također, sudjelovanjem u mrežnim raspravama o knjigama knjižničari unapređuju znanje o knjigama. ${ }^{25}$ Stoga im prisutnost na mrežnim raspravištima donosi višestruke koristi.

Još jedna prednost mrežnih rasprava prema Trottu jest to što se one mogu odvijati asinkrono. Svaki sudionik rasprave može joj doprinijeti u različito vrijeme, ovisno kada mu to odgovara. ${ }^{26}$ Trott također primjećuje da ima čitatelja koji izbjegavaju knjižničarima objašnjavati u čemu uživaju čitajući određene knjige. ${ }^{27}$ Taj tip čitatelja može biti sklon izbjegavanju izravne komunikacije s knjižničarom. U takvim situacijama mrežni servis savjetovanja postaje primjereniji način da knjižničar pomogne korisniku u izboru knjige za čitanje.

Stover također ističe da knjižničarima mogu koristiti slični portali jer na jednom mjestu okupljaju brojne informacije o knjigama. ${ }^{28}$ Skreće pažnju na to da korisnici u internetskoj komunikaciji upotrebljavaju knjižničarske opisne termine u svojem govoru o privlačnosti knjiga. ${ }^{29}$ Smatra da se „rađa web-nacija neformalnih savjetnika čitatelja“, tj. čitatelja koji pružaju drugim čitateljima savjete

\footnotetext{
22 Usp. Stover, K. M. Nav. dj., str. 244.

23 Usp. Trott, B. Nav. dj., str. 210.

24 Usp. Lockley, L. M.; L. Tarulli. All for one, one for all. // Reference \& User Services Quarterly 52, 2(2012), str. 100. Dostupno na: https://www.jstor.org/stable/pdf/refuseserq.52.2.98.pdf.

25 Usp. Stover, K. M. Nav. dj., str. 244.

26 Usp. Trott, B. Nav. dj., str. 322.

27 Usp. isto, str. 212.

28 Usp. Stover, K. M. Stalking the wild appeal factor: readers' advisory and social networking sites. // Reference \& User Services Quarterly 48, 3(2009), str. 269. [citirano: 2019-10-21]. Dostupno na: https://search.proquest.com/openview/651d473641c4fab2bbf2754ac9b782b8/1.

29 Usp. isto.
} 
vezane uz knjige i čitanje, iako nisu formalno obrazovani za tu aktivnost. Ti čitatelji savjetuju prijatelje i kolege o knjigama za čitanje, a pritom koriste izraze iz knjižničarstva, izraze koji se nalaze na policama knjiga, u oznakama, prikazima i anotacijama knjiga. ${ }^{30}$ Važno je da knjižničari prepoznaju da čitalačke društvene mreže donose rječnik privlačnosti knjige. ${ }^{31}$ Fenomen 'privlačnosti knjige' opisala je Saricks, predstavivši kategorije privlačnosti prema kojima se najčešće opisuju aspekti privlačnosti knjige za čitatelja. Navodi pet aspekata privlačnosti knjige: brzina razvoja radnje (pacing), karakterizacija (characterization), usmjerenost radnje (story line), okvir i ton (frame and tone) te stil (style). ${ }^{32}$ Rječnik privlačnosti skup je izraza koji ukazuju na određene aspekte privlačnosti knjige. Te izraze autori mogu koristiti u svojim opisima i recenzijama, tj. prikazima knjiga. Moguće korištenje tih izraza objasnit ćemo na primjeru aspekta privlačnosti knjige pod nazivom brzina razvoja radnje. Taj se aspekt odnosi na to ima li neka knjiga brzu, sporu ili normalnu brzinu razvoja radnje. Naprimjer postoje knjige koje nas svojom brzinom radnje toliko uvuku u priču da ih ne možemo odložiti. A postoje i knjige u kojima se radnja vrlo sporo odvija jer pisac veliku pažnju pridaje opisima okoline ili likova. Ako knjižničari poznaju brzinu razvoja radnje u knjigama, onda čitateljima mogu savjetovati posudbu knjiga i prema tom aspektu. Naprimjer čitatelj kojeg zanimaju knjige s brzim razvojem radnje može dobiti usmenu preporuku od knjižničara ili može o tome dobiti podatak u katalogu. Taj se aspekt privlačnosti knjige u pretraživanju kataloga može kombinirati s drugim aspektima privlačnosti knjige ili nekim drugim metapodacima poput žanra ili autora knjige. Ako su knjige označene u katalogu izrazima za različite aspekte privlačnosti, onda naprimjer čitatelj može zadati upit za pretraživanje kataloga tako da kombinira izraze dvaju ili više različitih aspekata privlačnosti knjige. Naprimjer može zadati upit da mu se izlistaju sve knjige koje imaju sljedeća tri obilježja: brzu radnju (aspekt brzine razvoja radnje), fokus na karakterizaciji likova (aspekt karakterizacije) i duhovit ton (aspekt okvira i tona). U narednom poglavlju detaljnije ćemo objasniti ostale aspekte privlačnosti knjige koje opisuje Saricks.

V. A. Caplinger ističe da dodavanje podataka o privlačnosti knjige u njezin kataložni zapis obogaćuje već prisutne informacije o žanru i predmetu opisane knjige te omogućuje pretraživanje kataložnih zapisa prema aspektima privlačnosti. ${ }^{33}$ Caplinger je imala priliku sudjelovati u izradi kontroliranog rječnika privlačnosti namijenjenoga za opis knjiga u katalogu NoveLista, portala za savjetovanje

\footnotetext{
30 Usp. isto, str. 246.

31 Usp. isto.

32 Usp. Saricks, J. Nav. dj., 44-64.

33 Usp. Caplinger, V. A. In the eye of the beholder: readers' advisory from a cataloging perspective. // Reference \& User Services Quarterly 52, 4(2013), str. 290. [citirano: 2019-10-21]. Dostupno na: https://search.proquest.com/openview/a013e4b90992804c861b369e443587fc/1.
} 
čitatelja. ${ }^{34}$ Zahvaljujući tomu svi zainteresirani za izgradnju sličnog rječnika mogu dobiti uvid u različite aspekte tog projekta u njezinu članku gdje, između ostaloga, navodi da su na temelju pregleda literature i vlastitih istraživanja i razmatranja sudionici projekta definirali četiri glavne kategorije, tj. aspekta privlačnosti: usmjerenost radnje, brzina razvoja radnje, ton i stil pisanja (storyline, pace, tone, writing style). ${ }^{35}$ Ovaj je projekt obogaćivanja kataloga omogućio korisnicima da u katalogu NoveList mogu preciznije obaviti pretraživanje zbirke koristeći i aspekte privlačnosti djela. Onima koji planiraju slične projekte koristan može biti i priručnik o tome na koje načine djelatnici NoveLista za opis knjiga koriste izraze privlačnosti i izraze za opis tema i žanrova djela. ${ }^{36} \mathrm{~L}$. Spiteri i J. Pecoskie izradile su na temelju postojećih taksonomija te na temelju detaljnog pregleda relevantne literature tri taksonomije povezane s afektima (affects): taksonomiju emocija, taksonomiju tonova i taksonomiju asocijacija. Tonovi su osobine djela koje potiču emocije kod čitatelja, npr. knjiga s jezovitim tonom kod čitatelja može izazvati emociju straha. Asocijacije se odnose na proces prisjećanja koji pobuđuje emocije. ${ }^{37} \mathrm{Na}-$ primjer asocijacija, tj. prisjećanje ,čitatelja na majčinstvo može utjecati na njegov ili njezin emocionalni odgovor na knjigu o djeci“". ${ }^{38}$ Spiteri i Pecoskie smatraju da se taksonomije emocija, tonova i asocijacija koje su izradile, mogu koristiti u savjetovanju čitatelja, kao i za unapređenje kataložnih zapisa kako bi se proširile mogućnosti pretraživanja i organizacije knjižnične građe ${ }^{39}$ Poticaj za istraživanje bio im je $u$ tome što su primijetile da se u literaturi s temom savjetovanja čitatelja spominje i emocionalno iskustvo čitatelja kao jedna od bitnih kategorija za opis i doživljaj djela, ali se ta kategorija nigdje detaljnije ne istražuje. ${ }^{40}$ Stoga su same istražile temu te napravile spomenute taksonomije, koristeći relevantnu literaturu i analizu korisničkih prikaza knjiga fikcije. Jedan od bitnih koraka koji mogu doprinijeti izradi kontroliranih rječnika privlačnosti definitivno je provođenje istraživanja o tome kojim se izrazima za opisivanje privlačnosti knjige služe korisnici. ${ }^{41}$ Također, za izradu što kvalitetnijeg rječnika privlačnosti od koristi mogu biti različita već provedena istraživanja povezana s tom temom kao što su prethodno opisana istraživanja Caplinger te Spiteri i Pecoskie. Ukratko ćemo predstaviti još

\footnotetext{
34 NoveList. [citirano: 2019-10-02]. Dostupno na: https://www.ebscohost.com/novelist.

35 Usp. Caplinger, V. A. Nav. dj., str. 288.

36 NoveList's Story Elements. [citirano: 2019-10-02]. Dostupno na: https://www.ebscohost.com/ novelist/idea-center/learn/learn-story-elements.

37 Usp. Spiteri, L.; J. Pecoskie. Expanding the scope of affect: taxonomy construction for emotions, tones, and associations. // Journal of Documentation 74, 2(2018), 383-397. [citirano: 201910-21]. Dostupno na: https://www.emerald.com/insight/content/doi/10.1108/JD-02-2017-0026/ full $/ \mathrm{html}$.

38 Isto, str. 385.

39 Usp. isto, str. 382.

40 Usp. isto, str. 384.

${ }^{41}$ Usp. Trott, B. Nav. dj., str. 214.
} 
nekoliko relevantnih radova. D. Adkins, J. S. Bossaller i H. M. Sandy istražili su na koji način u mrežnoj trgovini Amazon čitatelji opisuju multikulturalna djela fikcije. Metodom rudarenja podataka istražili su čitateljske prikaze tih djela te su odredili izraze kojima čitatelji opisuju djela. ${ }^{42}$ Istražujući temu klasifikacije djela fikcije, M. Ward i J. Saarti predstavili su mogućnost i potrebu izrade kataloga koji uključuje pretraživanje prema afektivnim, odnosno emotivnim aspektima fiktivnih djela, tj. odnosa čitatelja prema tim djelima. ${ }^{43}$ Opisuju izazove prisutne kod stvaranja kontroliranog rječnika za opis afektivne dimenzije djela, pa naprimjer ukazuju na to da posebnu brigu kod definiranja rječničkih termina treba posvetiti vrlo subjektivnim terminima poput termina 'smiješno' (funny). Naime korisnici koji će pretraživati katalog prema tom terminu mogu imati vrlo različito razumijevanje sadržaja opisanog tim terminom ili sličnim vrlo subjektivnim terminima. Dok jednom korisniku sadržaj knjige može biti vrlo smiješan, drugome korisniku isti taj sadržaj nije nimalo smiješan. ${ }^{44}$ A. Šauperl analizirala je korisničke prikaze i tagove knjiga fikcije na portalima Amazon, LibraryThing te slovenskom portalu za promociju knjiga Primorci beremo. Svrha analize bila je da se na temelju saznanja o korisničkim opisima knjiga unaprijede knjižnični katalozi. Jedan od uvida stečenih tim istraživanjem jest da u prikazima na LibraryThingu i Amazonu korisnici najčešće opisuju sljedeće aspekte knjige: žanr, tema, autor, pozicija u povijesti književnosti, lokacija i stil. ${ }^{45}$ Onima koji istražuju kako čitatelji opisuju pročitane knjige od znatne je pomoći kada imaju na raspolaganju bazu podataka u kojoj su prikupljeni i objedinjeni prikazi koje čitatelji pišu na različitim mrežnim sjedištima. To je razlog zbog kojeg P. Boot zagovara izgradnju sličnih baza podataka, uzimajući kao primjer već postojeću bazu podataka pod nazivom 'Nizozemske reakcije na knjige u mrežnom okruženju’ (Online Dutch Book Response). ${ }^{46}$

\footnotetext{
${ }^{42}$ Adkins, D.; J. S. Bossaller; Sandy, H. M. Exploring reader-generated language to describe multicultural literature. // The International Journal of Information, Diversity, \& Inclusion 3, 2(2019), 1-20. [citirano: 2019-10-21]. Dostupno na: https://jps.library.utoronto.ca/index.php/ijidi/ article/view/32591.

43 Usp. Ward, M.; J. Saarti. Reviewing, rebutting, and reimagining fiction classification. // Cataloging \& Classification Quarterly 56, 4(2018), str. 1. [citirano: 2019-10-21]. Dostupno na: https:// www.tandfonline.com/doi/abs/10.1080/01639374.2017.1411414.

44 Usp. isto, str. 6.

45 Šauperl, A. Pinning down a novel: characteristics of literary works as perceived by readers. // Library Review 61. 4(2012), str. 293. [citirano: 2019-10-21]. Dostupno na: https://www.emerald. com/insight/content/doi/10.1108/00242531211267581/full/html.

46 Boot, P. The desirability of a corpus of online book responses. // Proceedings of the Second Workshop on Computational Linguistics for Literature / ed. by David Elson, Anna Kazantseva and Stan Szpakowicz, Stroudsburg, USA: The Association for Computational Linguistics, 2013. Str. 32-40.; također, Boot, P. A Database of online book response and the nature of the literary thriller. // Conference: Digital Humanities 2017, Montreal, Canada. [citirano: 2019-10-01]. Dostupno na: https://dh2017.adho.org/abstracts/208/208.pdf.
} 


\section{Privlačnost knjige}

Nezaobilazan element savjetovanja čitatelja jest privlačnost knjige (book appeal). Termin objašnjava Saricks, čija je knjiga Usluga savjetovanja čitatelja $u$ narodnoj knjižnici ključna za razumijevanje ovoga pojma i njegove važnosti za uslugu savjetovanja čitatelja. Saricks tvrdi da se termin privlačnosti knjige odnosi na elemente u knjizi koji doprinose čitateljevu uživanju u knjizi. ${ }^{47}$ Taj pojam odnosi se na sve razloge zbog kojih se nekom čitatelju određena knjiga sviđa. K. Dali smatra da je privlačnost knjige bitan razlog rekreativnog čitanja ${ }^{48}$, ali i sastavni dio samoga procesa čitanja. ${ }^{49}$ Čitatelj se oslanja na aspekte privlačnosti knjige kada objašnjava zbog čega ga je neka knjiga privukla, a privlačnost je ono što traži u novim naslovima koje namjerava čitati. Saricks opisuje korištenje aspekata privlačnosti na primjeru knjige 'Legalni triler' autora Steve Martinija. Kada koristimo aspekte privlačnosti knjige za opis ove knjige, onda se može iskazati da knjiga ima: brz razvoj radnje, da je to knjiga zbog koje se jedva čeka okrenuti stranicu (page-turner); da autor predstavlja likove, tj. karaktere s kojima se možemo poistovjetiti i za koje smo zainteresirani; da u radnji postoje preokreti, neočekivana iznenađenja; da možemo uroniti u detalje sudskog procesa ili u neobične elemente zakona oko kojega se vrti radnja; i naposljetku da je ton knjige optimističan, na kraju pobijedi onaj koji je imao manju šansu da pobijedi (underdog hero). ${ }^{50}$

Saricks također navodi da čitatelji i savjetnici čitatelja često prepoznaju privlačnost knjige i prije nego što ju mogu definirati, tj. prije nego što mogu jasno izraziti od čega se sastoji ta privlačnost. Smatra da su te skupine razvile šesto čulo za prepoznavanje aspekata privlačnosti knjige. Čitateljskim savjetnicima posebno će koristiti razvoj sposobnosti prepoznavanja i jasnog opisa aspekata privlačnosti knjige jer uz pomoć njih mogu unaprijediti svoj rad te ponuditi čitateljima dodatne relevantne informacije za otkrivanje zanimljivog čitalačkog štiva. ${ }^{51}$ Kao što smo naveli u prethodnom poglavlju, Saricks ističe pet aspekata privlačnosti knjige: brzina razvoja radnje (pacing), karakterizacija (characterization), usmjerenost radnje (story line), okvir i ton (frame and tone) te stil (style). ${ }^{52}$ Ističe da taj popis nije konačan, ali pruža dobro polazište za razumijevanje privlačnosti knjige.$^{53} \mathrm{U}$ prethodnom poglavlju objasnili smo značenje jednog od tih aspekata privlačnosti knjige: brzina razvoja radnje. Sada ćemo predstaviti i preostala četiri aspekta pri-

\footnotetext{
47 Usp. Saricks, Joyce. Nav. dj., str. 11.

48 Usp. Dali, K. From book appeal to reading appeal: redefining the concept of appeal in readers' advisory. // The Library Quarterly: Information, Community, Policy 84, 1(2014), str. 31. [citirano: 2019-10-21]. Dostupno na: https://www.journals.uchicago.edu/doi/abs/10.1086/674034.

49 Usp. isto, str. 37.

s0 Saricks, Joyce. Nav. dj., str. 43-44.

51 Usp. isto, str. 42.

52 Usp. isto, str. 44-64.

53 Usp. isto, str. 40.
} 
vlačnosti. Karakterizacija je aspekt privlačnosti knjige koji se odnosi na načine na koje autor prikazuje karaktere likova. Aspekt karakterizacije u određenoj se knjizi odnosi na to predstavljaju li se karakteri likova postupno tijekom duljeg vremena ili se njihovi karakteri odmah razaznaju; je li fokus na jednom liku ili na nekoliko likova čiji se životi isprepleću; iz koje se perspektive pripovijeda priča; je li karakterizacija najvažniji aspekt knjige; treba li se čitatelj poistovjetiti s likovima ili ih treba samo promatrati; postoje li likovi čije aktivnosti i razvoj možemo pratiti u nekoliko povezanih romana; ima li u knjizi zapamtljivih i važnih sporednih likova. ${ }^{54}$ Još jedan od aspekata privlačnosti knjige jest usmjerenost radnje. Taj aspekt privlačnosti knjige odnosi se na način na koji autor prikazuje radnju knjige. Aspekt usmjerenosti radnje u određenoj se knjizi odnosi na to je li u radnji naglasak na likovima ili na situacijama i događanjima; također, odnosi se na namjeru autora s obzirom na radnju; je li radnja više fokusirana introspekcijski i psihološki ili je fokus radnje više na vanjskim, akcijskim zbivanjima; odvija li se radnja na više razina? ${ }^{55} \mathrm{Za}$ sve te odrednice usmjerenosti radnje Saricks pruža detaljnija objašnjenja, pa naprimjer za odrednicu odvija li se radnja na više razina piše da se pod time misli na to teče li radnja u jednoj neprekinutoj priči s rijetkim sporednim dijelovima priče ili je ispripovijedana putem više isprepletenih paralelnih priča. ${ }^{56}$

Okvir i ton čine aspekt privlačnosti knjige koji se odnosi na atmosferu, tj. osjećaj koji stvara pozadinski svijet u kojem se odvija glavna radnja knjige (background). Naprimjer knjiga može imati prijeteću, optimističnu, upozoravajuću, duhovitu, magičnu ili romantičnu atmosferu. Aspekt okvira i tona u određenoj se knjizi odnosi na to je li okolina u kojoj se odvija glavna radnja knjige opisana detaljno ili minimalno; utječe li opis okoline na atmosferu u kojoj se odvija radnja; stvara li autor posebnu okolinu, tj. poseban svijet u kojemu se odvija radnja knjige. ${ }^{57}$ Zanimljivo je da Saricks ne daje detaljnija objašnjenja za aspekt privlačnosti knjige pod nazivom stil, osim što navodi primjere izraza kojima se stil pisanja knjige može opisati, naprimjer: klasičan, složen, razgovorni, direktni, dramatični, razrađeni, elegantni, ekstravagantni, iskreni, elegantni, žanrovski, prirodni, poetični, prozni, suzdržani, sofisticirani, promišljeni. ${ }^{58}$

Izrazi koji se koriste za opis privlačnosti dodatne su informacije koje korisnicima pomažu u donošenju odluke hoće li određenu knjigu čitati ili neće. Izrazi privlačnosti donose i jednu veliku prednost za knjižničare, a to je da njima mogu opisati knjige uz manje pamćenja detalja iz same knjige te bez otkrivanja njezina sadržaja ${ }^{59}$ Također, izrazi privlačnosti omogućuju knjižničarima da s puno

\footnotetext{
54 Usp. isto, str. 50.

55 Usp. isto, str. 55-56.

56 Usp. isto, str. 57.

57 Usp. isto, str. 59.

58 Usp. isto, str. 66.

59 Usp. isto, str. 43.
} 
više samopouzdanja govore o knjigama koje nisu pročitali. ${ }^{60}$ Svijest o postojanju određenih aspekata privlačnosti knjiga, a osobito znanje o tome kako te aspekte izraziti, doprinosi kvaliteti razgovora čitatelja i knjižničara, kojemu je cilj pružanje preporuka za čitanje. Čitatelj osvještava što mu se kod neke knjige sviđa, a knjižničaru je lakše odrediti koje druge knjige posjeduju kvalitete koje čitatelj smatra privlačnima. Saricks navodi da za opis privlačnosti knjige nije nužno imati kontrolirani rječnik. ${ }^{61}$ Smatra da knjižničari moraju biti svjesniji izraza koji se pojavljuju u razgovorima s čitateljima o knjigama i njihovoj privlačnosti, jer to su izrazi koje upotrebljavaju korisnici i ukazuju na mogućnosti opisa privlačnosti. ${ }^{62}$ Dobar su izvor izraza za opis privlačnosti recenzije, tj. prikazi knjiga, koje knjižničari moraju sustavno pratiti. ${ }^{63}$ Za knjižničare je važno znati na koja obilježja knjige privući pozornost čitatelja. Trebaju dobro razumjeti obilježja koji knjigu čine atraktivnom i zanimljivom za čitatelja. ${ }^{64}$

Dali nadopunjuje tumačenje privlačnosti knjige koje daje Saricks jer smatra da obilježja koja proizlaze samo iz knjige nisu dovoljna za učinkovito savjetovanje čitatelja. Predlaže razumijevanje privlačnosti kao „moći da se probudi zanimanje za čitanje i pokrene radnja čitanja “ ${ }^{65}$ Taj pristup dovodi do sveobuhvatnijeg koncepta 'čitalačke privlačnosti' (engl. reading appeal) koji se razlikuje od termina 'privlačnosti knjige' (book appeal) ${ }^{66}$ Dali uočava da Saricks u svojoj definiciji pojma privlačnosti ne uključuje čitateljevu osobnu situaciju, kao ni njegovu osobnost i potrebe. ${ }^{67}$ Smatra da, uz obilježja knjige, u definiranje privlačnosti knjige treba uključiti i obilježja čitatelja. Za Dali je 'čitalačka privlačnost' pojam koji se sastoji od dvije dimenzije: jedne koja se odnosi na obilježja knjige i druge koja ovisi o čitatelju. ${ }^{68}$ Dali smatra da određene knjige svoju popularnost duguju činjenici da o njima čitatelji raspravljaju. Čitatelji ih čitaju da bi se uključili u društvo. Manje ih privlače kvalitete određene knjige, a više učinak njezina čitanja na povezivanje s drugim čitateljima. ${ }^{69}$ Moguće je da čitatelji žele pročitati knjigu koja se ne uklapa u njihov uobičajeni izbor samo zato što se o toj knjizi raspravlja, zato što se na raznim mjestima nalaze podaci o

60 Usp. isto.

${ }_{61} \quad$ Usp. isto, str. 65.

62 Usp. isto, str. 65-66.

63 Usp. isto, str. 67.

${ }^{64}$ Usp. Smith, D. Talking with readers: a competency based approach to readers' advisory service. // Reference \& User Services Quarterly 40, 2(2000), str. 139. [citirano: 2019-10-21]. Dostupno na: https://search.proquest.com/openview/962dd40e6c6da1853649753b99d1f668/1.

${ }_{65}$ Usp. Dali, K., Nav. dj., str. 24.

66 Isto.

67 Usp. isto.

68 Isto, str. 41.

69 Usp. Dali, K. Nav. dj., str. 39. 
njoj i što se uključivanjem u zajednicu čitatelja te knjige čitatelji socijaliziraju. Sličan stav zauzima i Caplinger, koja smatra da privlačnost knjige ovisi i o tome kako čitatelj reagira na nju. ${ }^{70}$ Takvi stavovi o razumijevanju privlačnosti knjige nisu bezrazložni, jer je jasno da svaka knjiga odgovara drukčijem korisniku, ovisno o njegovim osobnim obilježjima.

Y. Naik istražila je utjecaj koji na korisnike imaju preporuke za čitanje s portala Goodreads tako što je analizirala prikaze knjiga i čitateljske komentare vezane uz te prikaze. Otkrila je da preporuke utječu na odabir knjiga za čitanje te preporučila knjižničarima kako koristiti Goodreads u radu. ${ }^{71}$ Smatra da bi se daljnja istraživanja Goodreadsa mogla usmjeriti na preporuke knjiga za čitanje, da bi se moglo ispitati korisnike Goodreadsa jesu li im rasprave na tom portalu pomogle u odabiru knjiga za čitanje te da bi se moglo istražiti što sve korisnici smatraju korisnim na portalu Goodreads. ${ }^{72}$

\section{Istraživanje}

\subsection{Uvod u istraživanje}

Za ovo smo istraživanje odabrali portal Goodreads, portal o knjigama i društvenu mrežu za stvaranje zajednica čitatelja. U literaturi se spominju slični portali poput Shelfarija, Anobiija, LibraryThinga, BiblioEteca, Book Gluttona ${ }^{73}$, ali su oni ili ugašeni ili su daleko manje korišteni u usporedbi s Goodreadsom. Svaki korisnik Goodreadsa samostalno odabire koje će opcije ovog portala koristiti te hoće li za njega Goodreads biti primarno sredstvo za komunikaciju s drugim korisnicima ili će naglasak staviti na one alate koji se odnose na knjige. Moglo bi se reći da je upravo raznolikost ponude različitih aktivnosti bitan razlog zbog kojeg je Goodreads popularan među korisnicima. Korisnici odabiru kako će koristiti Goodreads: prvenstveno kao alat za svoju društvenu mrežu i komunikaciju, kao vlastiti virtualni čitateljski klub, kao mjesto za objavu svojeg mišljenja ili na neki drugi način.

\footnotetext{
70 Usp. Caplinger, V. A. Nav. dj., str. 288.

71 Usp. Naik, Y. Finding good reads on Goodreads: readers take RA into their own hands. // Readers' Advisory, 51, 4(2012), str. 322. [citirano: 2019-10-21]. Dostupno na: https://search.proquest.com/openview/13af6aa2927cf99374c6366467f65bdf/1.

72 Usp. isto, str. 323.

73 Usp. Cordón-García, J. A.; J. Alonso-Arévalo; R. Gómez-Díaz; D. Linder. Nav. dj., str. 165.
} 


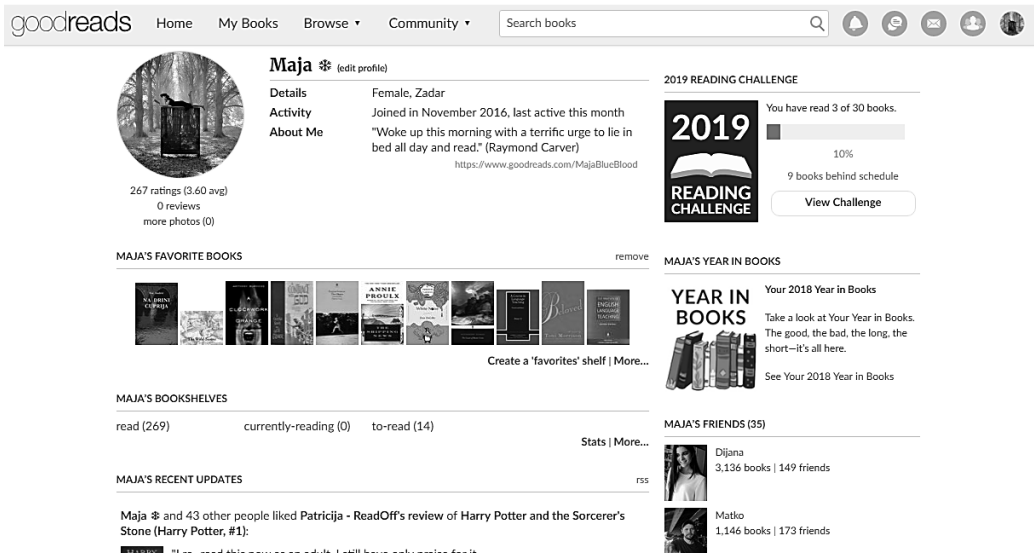

Slika 1. Profil korisnika na Goodreadsu

Odmah po prijavljivanju na stranicu Goodreadsa, korisnicima su ponuđene tri 'virtualne police' za knjige: police 'pročitano', 'trenutno čitam' i ‘želim pročitati'. Na njih korisnici slažu knjige te ih mogu proširivati dodatnim policama. Knjige koje slažu na policama Goodreadsa vidljive su kad se pogleda profil korisnika, pa ne služe samo za to da korisnik prati ono što je pročitao ili namjerava pročitati već imaju i funkciju prezentiranja korisnika kako bi mogao privući one sa sličnim ukusom u izboru knjiga ${ }^{74}$ Korisnici tako predstavljaju sebe kroz knjige koje ih zanimaju.

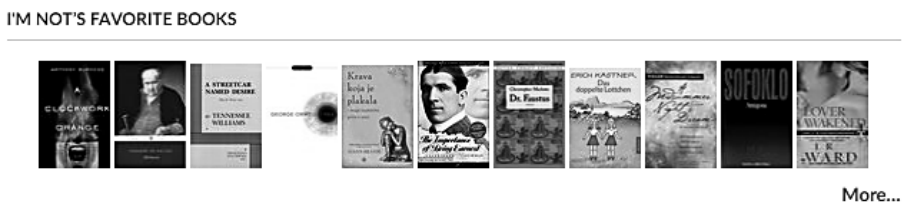

I'M NOT'S BOOKSHELVES

\begin{tabular}{|c|c|c|c|}
\hline $\begin{array}{l}\text { read (380) } \\
\text { currently-reading (5) } \\
\text { to-read (558) } \\
\text { maybe (131) } \\
\text { gave-up (43) } \\
\text { dnf-will-try-again (26) } \\
\text { couldnt-get-into-it (19) } \\
\text { on-hold (5) } \\
\text { young-adult (184) } \\
\text { mystery-thriller (168) } \\
\text { classics (101) } \\
\text { school-reads (95) }\end{array}$ & $\begin{array}{l}\text { paranormal (92) } \\
\text { guilty-pleasures (81) } \\
\text { chick-lit (80) } \\
\text { sf (76) } \\
\text { non-fiction (65) } \\
\text { fantasy (64) } \\
\text { historical-fiction (62) } \\
\text { dystopias (57) } \\
\text { will-probably-reread (... } \\
\text { exists-in-cro (53) } \\
\text { great-recs (52) } \\
\text { favorites (51) }\end{array}$ & $\begin{array}{l}\text { w-reads (46) } \\
\text { romantic-suspense (37) } \\
\text { tbr-owned (35) } \\
\text { plays (31) } \\
\text { short-stories (31) } \\
\text { damn-good-book (28) } \\
\text { tbr-shortlist (27) } \\
\text { new-adult (26) } \\
\text { waste-of-my-time (22) } \\
\text { not-sure-gotta-reread... } \\
\text { great-to-meh (18) } \\
\text { god-awful (15) }\end{array}$ & $\begin{array}{l}\text { Igbt (15) } \\
\text { struggled-to-finish (15) } \\
\text { writing-craft (14) } \\
\text { beta-reads (12) } \\
\text { sorry-not-for-me (12) } \\
\text { neighbouring-eds (8) } \\
\text { adaptation-trumps-it (.. } \\
\text { magic-realism (3) } \\
\text { audiobook (2) } \\
\text { ws-reads (2) } \\
\text { self-help (1) }\end{array}$ \\
\hline
\end{tabular}

Slika 2. Proširene 'knjižne police' korisnika na Goodreadsu

${ }_{74}$ Usp. isto, str. 974. 
Korisnicima je omogućeno da ocjenjuju knjige, označavaju ih tagovima, tj. opisnim oznakama, da o njima pišu prikaze i sudjeluju u raspravama, što znači da ostalim korisnicima osiguravaju informacije o knjigama. Goodreads time potiče povezivanje korisnika sličnih interesa i razmišljanja o knjigama. Cordón-García i suradnici smatraju da se „prava socijalizacija čitanja događa samo onda kada su barijere udaljenosti i vremena prevladane i čitanje se odvija u globalnoj areni, pretvarajući same knjige u mjesta susreta." 75

Goodreadsovi virtualni klubovi čitatelja i opcije stvaranja zajednica čitatelja diljem svijeta uklanjaju granice koje postoje u fizičkom svijetu. Tako se stvara globalna arena čitatelja o kojoj govore Cordón-García i suradnici.

$\mathrm{S}$ razmjenom mišljenja o knjigama povezan je i sustav preporuka knjiga. Naime Goodreads će svakome korisniku preporučiti određene knjige i čitateljske grupe na temelju knjiga koje korisnik ima na svojoj polici. Preporuke korisnici mogu dobivati i jedni od drugih, a upravo taj fenomen vrijedilo bi detaljnije istražiti. Naime uočava se trend da se korisnici u potragama za novim naslovima za čitanje sve više oslanjaju na mrežne izvore i preporuke poznanika. ${ }^{76} \mathrm{U}$ međusobnim mrežnim razgovorima, komentarima i raspravama uočava se da čitatelji koriste knjižničarske vještine i strategije savjetovanja čitatelja. ${ }^{77}$ Naime korisnici Goodreadsa jedni će drugima sugerirati trebaju li neku knjigu čitati ili ne. To mogu napraviti u komentarima ili prikazima koje napišu o nekoj knjizi ili izravno, opcijom 'Preporuči' (Recommend) koju Goodreads omogućuje. Međutim kada je riječ o preporukama, Y. Naik primjećuje da među korisnicima Goodreadsa snažno djeluje sila povjerenja, pa obično korisnici spremnije sudjeluju u raspravama i prihvaćaju preporuke kada one dolaze od nekoga koga poznaju, tko je dio njihove društvene mreže. ${ }^{78}$ To upućuje na potrebu za društvenim kontaktom s već poznatim ljudima, čak i u virtualnom okruženju.

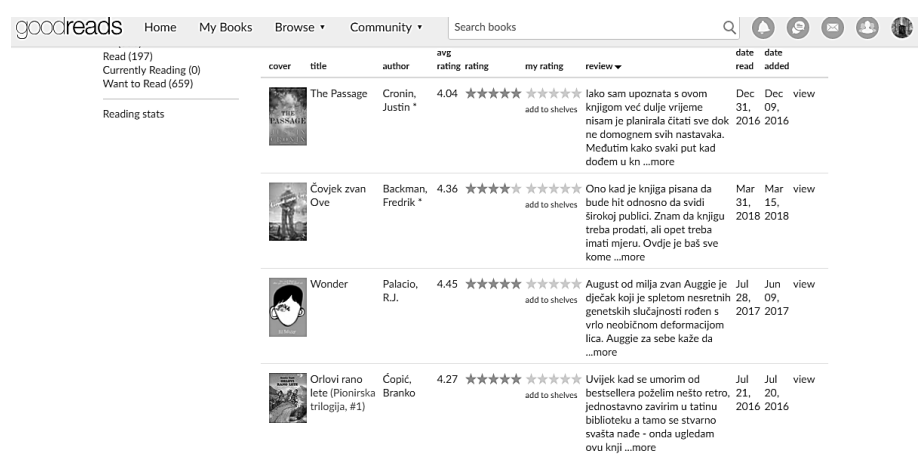

Slika 3. Polica 'Pročitano' (Read) na Goodreadsu s ocjenama i prikazima knjiga koje je korisnik pročitao

\footnotetext{
75 Usp. Cordón-García, J. A.; J. Alonso-Arévalo; R. Gómez-Díaz; D. Linder. Nav. dj., str. 189.

76 Usp. isto, str. 176.

77 Usp. Naik, Y. Nav. dj., str. 320.

78 Usp. isto, str. 321.
} 
Čitatelji na Goodreadsu raspravljaju o knjigama koristeći u opisima knjiga izraze za opis privlačnosti knjige. Oni nisu stručnjaci u opisu knjiga, već ih opisuju spontano, ponekad sami otkrivajući što ih kod nekog naslova privlači. Pritom se koriste prirodnim jezikom, stvarajući bogate opise knjiga. Iako se ti opisi u recenzijama korisnika mogu doimati nesustavnima, knjižničari i drugi informacijski stručnjaci od njih mogu imati koristi. Naime osim što mogu utvrditi koje su knjige popularne na mreži, mogu utvrditi i kako ih čitatelji opisuju te iz njihovih opisa izdvojiti brojne izraze i pristupe za izražavanje privlačnosti knjiga.

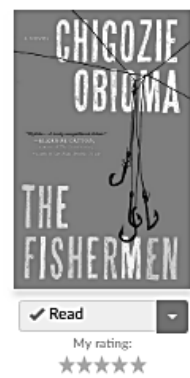

\section{The Fishermen}

by Chigozie Obioma (Goodreads Author)

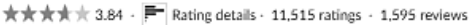

A striking debut novel about an unforgettable childhood, by a Nigerian writer the New York Times has crowned "the heir to Chinua Achebe."

Told by nine-year-old Benjamin, the youngest of four brothers, THE FISHERMEN is the Cain and Abel-esque story of a childhood in Nigeria, in the small town of Akure. When their father has to travel to a distant city for work, the brothers ...more

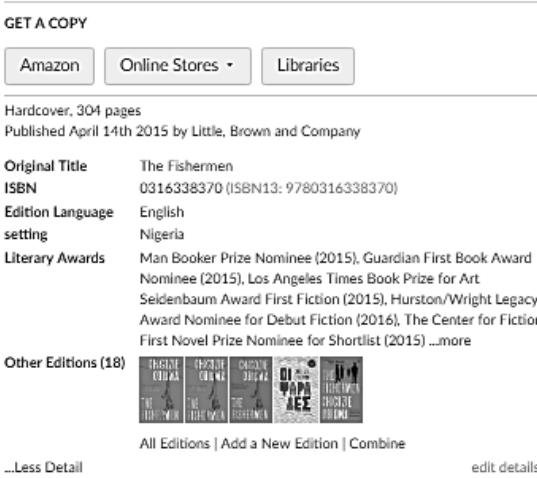

edit details

MYACTIVITY

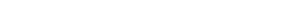

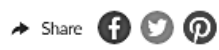

Recommend It | Stats | Recent Status Updates

READERS ALSO ENJOYED

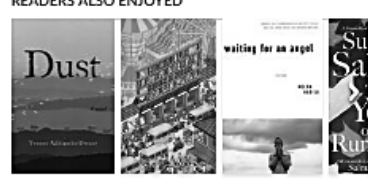

See similar books

\begin{tabular}{lr}
\hline GENRES & \\
\hline Fiction & 542 users \\
\hline Cultural $~>$ Africa & 263 users \\
\hline Western Africa $>$ Nigeria & 101 users \\
\hline Contemporary & 83 users \\
\hline Literary Fiction & 83 users \\
\hline Literature $\times$ African Literature & 56 users
\end{tabular}

See top shelves..

ABOUT CHIGOZIE OBIOMA

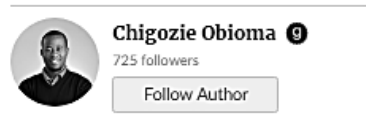

Chigozie Obioma was born in Akure, Nigeria. His debut novel, The Fishermen, is winner of the

Edit inaugural FT/Oppenheimer Award for Fiction, the NAACP Image Awards for Debut Literary

Slika 4. Izgled mrežne stranice knjige ‘The Fishermen’ na Goodreadsu

Važno je istaknuti i to da Goodreads sadrži mnogo različitih podatka o knjigama - sadrži 2.6 milijarde opisanih knjiga i 90 milijuna prikaza knjiga. ${ }^{79} \mathrm{Go}$ odreadsova stranica o pojedinoj knjizi sadrži sažetak njezine radnje, različite metapodatke o knjizi, povezuje knjigu s autorovim drugim djelima te s različitim Goodreadsovim popisima knjiga na kojima se ona nalazi. Na stranici o pojedinoj knjizi također se nalaze rasprave koje su pokrenuli korisnici, a tu su i njihovi prikazi i ocjene knjige.

79 Usp. Goodreads. About us [citirano: 2018-8-11]. Dostupno na: https://www.goodreads.com/ about/us. 


\subsection{Metodologïa istraživanja}

\subsubsection{Ciljevi i svrha rada}

Cilj je ovog rada istražiti upotrebu portala za savjetovanje čitatelja Goodreads od strane korisnika iz Hrvatske s fokusom na aktivnosti savjetovanja čitatelja: pisanje i čitanje prikaza knjiga te preporuka za čitanje. Također, cilj rada bio je utvrditi koje sve izraze korisnici upotrebljavaju u svojim prikazima knjiga na Goodreadsu nastojeći opisati različite vidove privlačnosti knjige.

Svrha je rada upoznati stručnu zajednicu s mogućnostima korištenja podataka s portala Goodreads u knjižničnim aktivnostima (savjetovanje čitatelja, izrada kataloga). Također, svrha je rada predstaviti literaturu vezanu uz Goodreads i savjetovanje čitatelja, kao i predstaviti pojam privlačnosti knjige.

\subsubsection{Istraživačka pitanja}

Istraživanjem se nastoji odgovoriti na sljedeća istraživačka pitanja:

1) Na koji način korisnici iz Hrvatske koriste portal Goodreads?

2) Koje sve izraze za opis privlačnosti knjige korisnici upotrebljavaju u svojim prikazima knjiga na portalu Goodreads?

\subsubsection{Metoda, uzorak i tijek istraživanja}

Da bi se odgovorilo na prvo istraživačko pitanje, korištena je metoda online ankete za korisnike Goodreadsa iz Hrvatske. Na Goodreadsu postoji puno različith grupa korisnika. Jedna od grupa ima naziv CROATIA/grupa za čitatelje iz Hrvatske i na hrvatskom jeziku.$^{80}$ Anketa je upućena korisnicima te grupe putem opcije Goodreadsa za slanje privatnih poruka. U trenutku slanja ankete grupa je imala 1683 člana. Ukupno je kontaktirano 1107 članova. Anketa nije poslana članovima koji su na Goodreadsu bili neaktivni dulje od osam mjeseci te članovima koji su u postavkama onemogućili da im se šalju poruke. Članovi su kontaktirani u razdoblju od 13. ožujka do 13. travnja 2019. Od ukupnog broja osoba koje su pozvane da sudjeluju u istraživanju, 284 člana iz Hrvatske odgovorila su na sva pitanja u anketi, tj. odazvalo se $26 \%$ od ukupnog broja kontaktiranih korisnika. Ispitanicima je osigurana anonimnost.

Anketa se sastojala od 17 pitanja. Prvih 14 pitanja bilo je zatvorenog tipa, a posljednja tri pitanja bila su otvorenog tipa kako bi korisnici mogli upisati svoje mišljenje o dobrim ili lošim stranama Goodreadsa te unijeti po želji dodatne komentare.

80 Goodreads: CROATIA / grupa za čitatelje iz Hrvatske i na hrvatskom jeziku. [citirano: 20198-11]. Dostupno na: https://www.goodreads.com/group/show/2075-croatia-grupa-za-itatelje-izhrvatske-i-na-hrvatskom-jeziku. 
Anketom se ispitalo različite aspekte korištenja Goodreadsa kako bi se dobilo odgovor na istraživačko pitanje Na koji način korisnici iz Hrvatske koriste portal Goodreads?

Postavljena su pitanja o spolu i dobi ispitanika, državi iz koje dolaze te duljini članstva na Goodreadsu. Postavljena su potom pitanja o njihovim aktivnostima na tom portalu: objavljuju li prikaze knjiga i, ako da, zašto ih objavljuju; čitaju li i komentiraju prikaze drugih članova; daju li u svojim prikazima preporuke koje knjige čitati, a koje ne čitati te jesu li se sami odlučili pročitati neku knjigu na temelju prikaza napisanog od člana Goodreadsa i u koje svrhe koriste Goodreads?

Da bi se odgovorilo na drugo istraživačko pitanje, korištena je metoda sadržajne analize dvadeset recenzija, tj. prikaza knjiga koje su na Goodreadsu napisali korisnici iz navedene grupe. Nastojalo se istražiti koje izraze korisnici Goodread$s a$ u svojim prikazima pročitanih knjiga upotrebljavaju da bi opisali različite aspekte privlačnosti recenzirane knjige. Sadržajna je analiza provedena na temelju kategorija, tj. aspekata privlačnosti knjige koje je predložila Joyce Saricks. Izrazi iz korisničkih prikaza knjiga kategorizirani su na temelju njezinih pet kategorija privlačnosti knjige: brzina razvoja radnje (pacing), karakterizacija (characterization), usmjerenost radnje (story line), okvir i ton (frame and tone) te stil (style). ${ }^{81}$ Cilj je bio da se sadržajnom analizom u prikazima knjiga pronađu i kategoriziraju izrazi kojima članovi Gooodreadsa opisuju privlačnost knjige. Analizirano je dvadeset prikaza koje je napisalo dvadeset članova grupe CROATIA/grupa za čitatelje iz Hrvatske i na hrvatskom jeziku. Uzorak od dvadeset prikaza nije velik, ali je dovoljan da se u njemu pronađu različiti izrazi za opis privlačnosti knjiga. U dodatnim istraživanjima može se uključiti veći broj korisničkih prikaza kako bi se proširio skup izraza privlačnosti korištenih u njima. Za analizu su odabrani prikazi koji imaju minimalno 500 i maksimalno 3000 znakova, a napisani su na hrvatskom jeziku. Odabir prikaza rađen je tako da se pregledao popis članova već navedene grupe na Goodreadsu. Na profilu svakog člana nalazi se podatak o tome koliko ima recenzija pa je kod korisnika koji stvaraju vlastite prikaze popis recenziranih knjiga otvoren i proučen. Za analizu su odabrani naslovi koje su korisnici posljednje dododali na popis, a koji odgovaraju već navedenim kriterijima dužine i jezika kojim su napisani. Budući da se pretpostavljalo da djela fikcije sadržavaju sve elemente privlačnosti, dok u nefikciji oni često nisu svi prisutni, fikciji je u odabiru dana prednost. U ovih dvadeset prikaza opisano je devetnaest različitih naslova knjiga jer se dva prikaza odnose na isti naslov knjige. U tablici 1 navedeni su naslovi knjiga.

${ }_{81}$ Usp. Saricks, J. Nav. dj., str. 44-64. 
Tablica 1. Naslovi knjiga čiji su prikazi analizirani

\begin{tabular}{|l|l|l|}
\hline $\begin{array}{l}\text { Pan } \\
\text { (Knut Hamsun) }\end{array}$ & $\begin{array}{l}\text { Čovjek zvan Ove } \\
\text { (Fredrik Backman) }\end{array}$ & $\begin{array}{l}\text { The Passage } \\
\text { (Justin Cronin) }\end{array}$ \\
\hline $\begin{array}{l}\text { „Svjetionik“ } \\
\text { (Virginia Woolf) }\end{array}$ & $\begin{array}{l}\text { Avanture nevaljale } \\
\text { djevojčice } \\
\text { (Mario Vargas Llosa) }\end{array}$ & $\begin{array}{l}\text { Kradljivica knjiga } \\
\text { (Markus Zusak) }\end{array}$ \\
\hline $\begin{array}{l}\text { The Immortalists } \\
\text { (Chloe Benjamin) }\end{array}$ & $\begin{array}{l}\text { The One } \\
\text { (John Marrs) }\end{array}$ & $\begin{array}{l}\text { Svijet se raspada } \\
\text { (Chinua Achebe) }\end{array}$ \\
\hline $\begin{array}{l}\text { Ivan Meštrović: } \\
\text { The Making Of A Master } \\
\text { (Maria Meštrović) }\end{array}$ & $\begin{array}{l}\text { Loaded } \\
\text { (Christos Tsiolkas) }\end{array}$ & $\begin{array}{l}\text { Kći Lotrščaka } \\
\text { (Marija Jurić Zagorka) }\end{array}$ \\
\hline $\begin{array}{l}\mathbf{1 0 0 \% ~ d r u s ̌ t v e n i ~ u z g o j ~} \\
\text { (Iva Tkalec) }\end{array}$ & $\begin{array}{l}\text { Pukotine \& druge priče } \\
\text { (Ivo Brešan) }\end{array}$ & $\begin{array}{l}\text { Gospodar muha } \\
\text { (William Golding) }\end{array}$ \\
\hline $\begin{array}{l}\text { Irbis } \\
\text { (Aleksandar Žiljak) }\end{array}$ & $\begin{array}{l}\text { Okovi prošlosti } \\
\text { (Andrea Tomić) }\end{array}$ & $\begin{array}{l}\text { American Gods } \\
\text { (Neil Gaiman) }\end{array}$ \\
\hline $\begin{array}{l}\text { Knjiga kratkih vječnih } \\
\text { ljubavi (Andreï Makine) }\end{array}$ & & \\
\hline
\end{tabular}

Osim što su istraživanjem u prikazima utvrđeni izrazi za opis privlačnosti knjige te svrstani u odgovarajućih pet kategorija (brzina razvoja radnje, karakterizacija, usmjerenost radnje, okvir i ton te stil), na temelju srodnosti u sadržaju pronađenih izraza također su definirane potkategorije pet kategorija privlačnosti knjige te su pronađeni izrazi raspoređeni unutar tih potkategorija.

\section{Rezultati istraživanja}

\subsection{Anketa za članove portala Goodreads iz Hrvatske}

Većinom su anketu ispunile osobe ženskog spola (206 žena ili 72,5\%). Najviše ispitanika pripada dobnoj skupini od 26 do 39 godina $(61,2 \%)$, a slijede osobe stare između 40 i 59 godina $(21,5 \%)$ te oni od 25 godina i mlađi (16,9\%). 85,2 $\%$ ispitanika odgovorilo je da su članovi Goodreadsa najmanje tri godine, što upućuje na zaključak da je većina ispitanika dobro upoznata s mogućnostima koje ovaj portal nudi.

Na slici 5 prikazano je koliko učestalo ispitanici pišu prikaze knjiga na $G o-$ odreadsu. Većina ispitanika, njih $65,5 \%$, piše prikaze o pročitanim knjigama. Najviše ispitanika piše prikaze samo za neke knjige koje su pročitali (51,06 \%), dok je ispitanika koji pišu prikaze za svaku pročitanu knjigu 10,92 \%. 


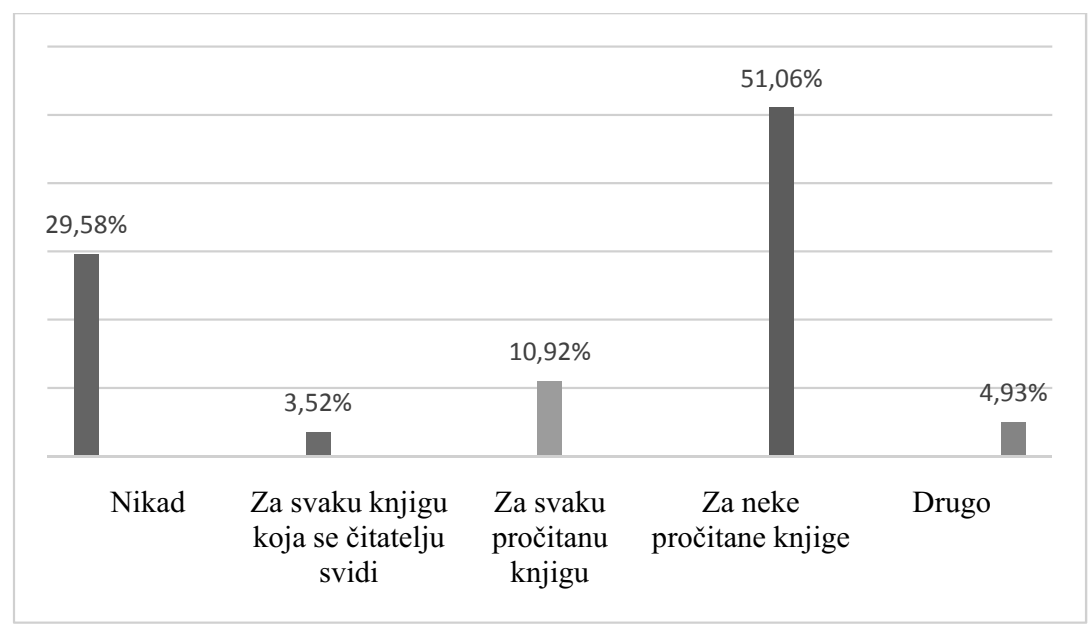

Slika 5. Učestalost pisanja prikaza knjiga na Goodreadsu

Razlozi pisanja prikaza knjiga prikazani su na slici 6. Najviše ispitanika piše prikaze kako bi izrazili mišljenje o knjigama koje su pročitali (53.1\%). Sličan broj ispitanika piše prikaze kako bi preporučili pročitane knjige drugim korisnicima Goodreadsa (40,49 \%). Na slici 6 nalazi se stavka 'Drugo', koja se odnosi na različite odgovore korisnika o razlozima pisanja prikaza. Kod te stavke najviše je korisnika, njih 18, odgovorilo da im pisanje prikaza služi kao podsjetnik na dojmljive knjige.

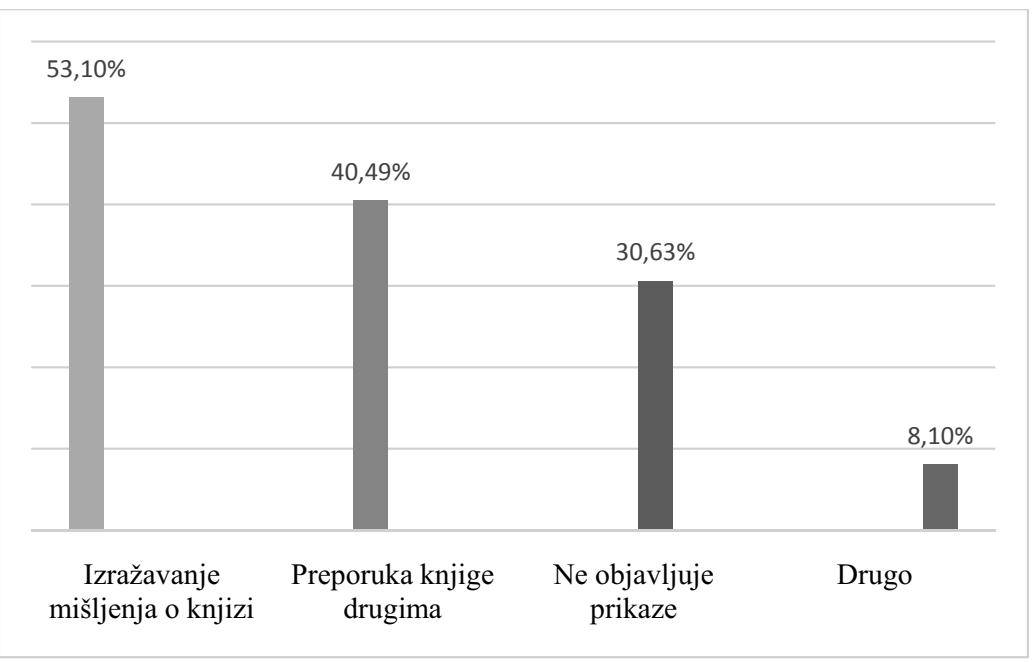

Slika 6. Razlog pisanja prikaza knjiga na Goodreadsu 
Osim što većina ispitanika piše prikaze knjiga na Goodreadsu, još je veći udio ispitanika koji čitaju te prikaze - njih čak $97,2 \%$. I komentiranje prikaza od strane ispitanika dosta je često - komentare piše $44,7 \%$ ispitanika.

Ispitanicima su postavljena i pitanja o tome prihvaćaju li preporuke za čitanje u prikazima drugih korisnika Goodreadsa te dodaju li u svojim prikazima knjiga i preporuke za čitanje. Iz slike 7 vidi se da je čak $87,7 \%$ ispitanika barem jednom odlučilo pročitati knjigu na temelju preporuke u nekom od prikaza na Goodread$s u$. Također, $46,1 \%$ ispitanika izjavilo je da u prikazima koje pišu drugima predlažu da pročitaju određenu knjigu.

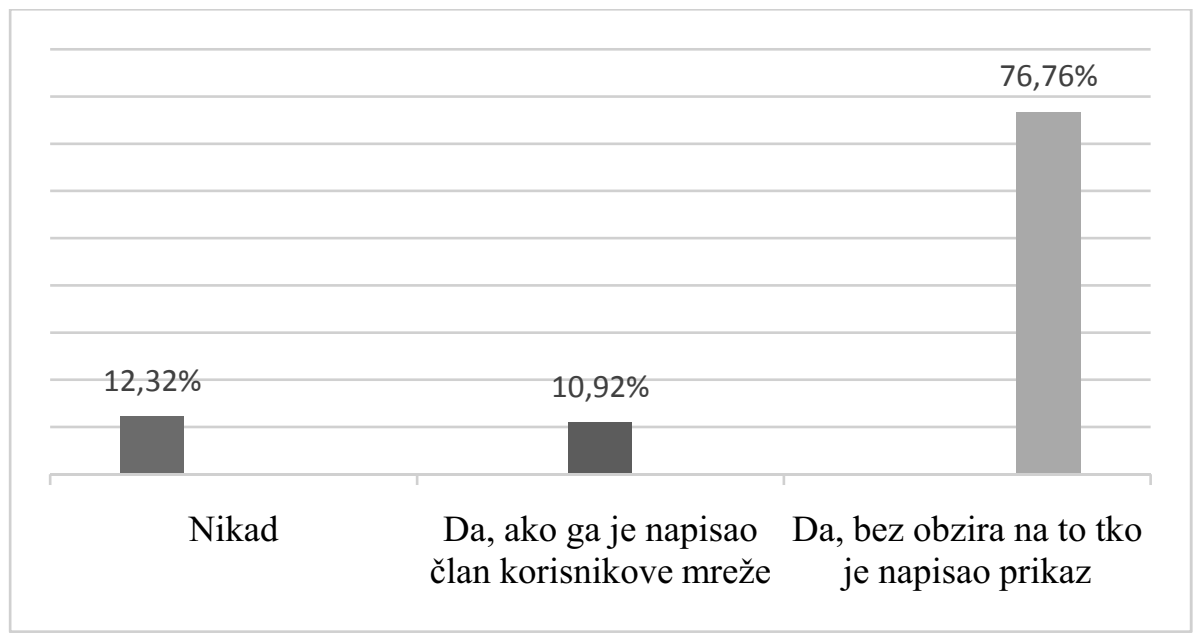

Slika 7. Učestalost čitanja knjige na temelju preporuke u prikazu na Goodreadsu

Još jedan od rezultata istraživanja jest da većina ispitanika, njih $60,2 \%$, ne koristi opciju 'Preporuči' (Recommend) kojom se može izravno preporučiti pojedina knjiga određenom članu Goodreadsa. 33,5\% ispitanika nikad nije dobilo preporuku na taj način, dok $52 \%$ ispitanika povremeno dobije i prihvati takvu preporuku.

Vezano uz općenita pitanja o korištenju Goodreadsa, ispitanici su se izjasnili o tome u koje sve svrhe koriste Goodreads (slika 8). Najviše ispitanika koristi Goodreads kako bi mogli pratiti što su sve pročitali $(89,44 \%)$. Većina ispitanika koristi ga kako bi dobila ideje za daljnje čitanje $(80,28 \%)$. Značajan udio ispitanika koristi portal kako bi čitao prikaze koje su napisali njegovi članovi $(44,37 \%)$. 


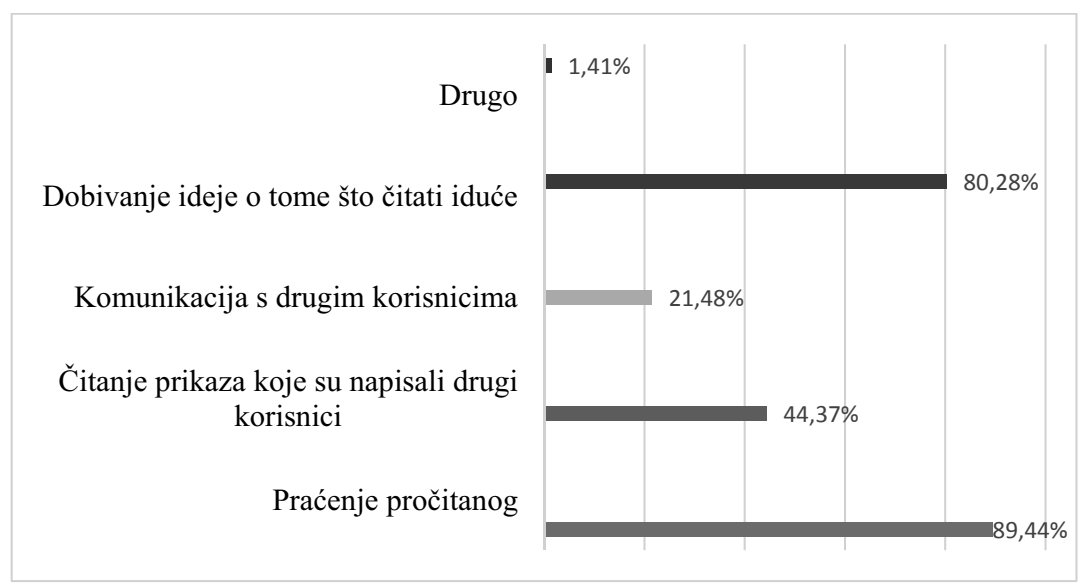

Slika 8. Razlozi za korištenje Goodreadsa

Među odgovorima na pitanje o tome što smatraju najkorisnijom stranom Goodreadsa po brojnosti se ističu sljedeći: korisnost praćenja pročitanih knjiga, dobivanje ideja o tome što bi naredno mogli čitati, čitanje prikaza drugih korisnika te obavijesti o novim izdanjima knjiga. Ispitanici često navode da je korisno i motivirajuće što na Goodreadsu imaju mogućnost odrediti broj knjiga koje će čitati u tekućoj godini (Reading Challenge).

Znatno manje ispitanika odgovorilo je na pitanje o nedostacima Goodreadsa, što upućuje na to da su uglavnom zadovoljni tim portalom. Tek je 11 ispitanika istaknulo da sustav ocjenjivanja knjiga nije dovoljno rafiniran, tj. da bi voljeli da se knjige mogu ocjenjivati većim rasponom bodova nego što su ocjene od jedan do pet.

$\mathrm{Na}$ posljednje pitanje o tome imaju li dodatnih komentara o Goodreadsu, 25 ispitanika istaknulo je da smatra da je to „odlična“ i „,najbolja“ stranica. O zadovoljstvu ispitanika Goodreadsom svjedoče njihovi komentari. Jedan od ispitanika navodi da je za njega Goodreads „super i stvarno odličan 'priručnik' za čitanje, ima hrpu opcija i puno mi je olakšano čitanje otkako ga koristim“. Drugi ispitanik navodi sljedeće: „Volim GR jer mi je pojednostavio čitanje, prati sve za mene. I sve je na jednom mjestu, vrlo pregledno i jednostavno.“

\subsection{Sadrăajna analiza prikaza knjiga na portalu Goodreads}

Sadržajnom analizom prikaza knjiga utvrđeno je da korisnici Goodreadsa koji pišu prikaze knjiga u njima često koriste izraze iz svih pet kategorija privlačnosti knjige, kako ih je predložila i opisala Joyce Saricks. Iako autorima ovih prikaza Goodreads ne daje upute da koriste izraze privlačnosti knjige, niti im zadaje obvezu da koriste te ili slične izraze, autori to ipak vrlo često čine. To nam potvrđuju podaci iz tablice $2 \mathrm{u}$ kojoj su prikazana čak 152 izraza za opis pet kategorija, tj. aspekata privlačnosti knjige, koji su pronađeni analizom sadržaja dvadeset korisničkih prikaza. Na temelju 
srodnosti u sadržaju pronađenih izraza, za svaku od pet kategorija privlačnosti potom smo definirali potkategorije i unutar ukupno 34 definirane potkategorije uvrstili smo pripadajuće izraze, što je također vidljivo u tablici 2 . Kategorizirani popis ovih izraza može biti koristan profesionalnim savjetnicima čitatelja, poput knjižničara, kako bi upoznali i razmotrili konkretne izraze koje koriste neprofesionalni savjetnici te stekli potpuniji uvid u način na koji oni opisuju pojedine kategorije i potkategorije privlačnosti knjige. Također, navedeni izrazi i potkategorije aspekata privlačnosti mogu pomoći u izradi kontroliranog rječnika privlačnosti, rječnika za opis knjiga i drugih tipova dokumenata, koji se može koristiti u kataložnom opisu.

Tablica 2. Izrazi za opis privlačnosti knjige korišteni u dvadeset prikaza na Goodreadsu svrstani u potkategorije

\begin{tabular}{|c|c|}
\hline $\begin{array}{c}\text { Kategorije } \\
\text { privlačnosti knjige }\end{array}$ & Izrazi i potkategorije za opis privlačnosti knjige \\
\hline $\begin{array}{l}\text { Brzina razvoja radnje } \\
\text { Ukupno } 7 \text { izraza podijel- } \\
\text { jenih u dvije potkategorije. }\end{array}$ & $\begin{array}{l}\text { BRZINA RAZVOJA POČETKA RADNJE ( } 4 \text { izraza): spor poče- } \\
\text { tak; dug uvod; dosadan početak; brzo počinje zaplet. } \\
\text { OSTALO (3): u ritmu godišnjih doba; sporo; temeljito; }\end{array}$ \\
\hline $\begin{array}{l}\text { Ukupno } 51 \text { izraz podi- } \\
\text { jeljen u sedam potkate- } \\
\text { gorija. }\end{array}$ & $\begin{array}{l}\text { OPIS OSOBINE LIKA (21 izraz): složen lik; ironična karikatura; } \\
\text { čangrizavac; bijesan na sve; pun principa; voli pravila i rutinu; nije } \\
\text { simpatičan; naporan; žena koja je unatoč neprestanoj neraspolože- } \\
\text { nosti i grubosti mekog srca; dobrodušan; strpljiv i brižan; nije netko } \\
\text { koga možete zavoljeti; lik budi paletu osjećaja; buntovan mladić; } \\
\text { dopadljivi likovi; plošni likovi; lik oslikava licemjerje; žena zano- } \\
\text { vijetalo; misteriozan lik; želja za slobodom i nada koje drže svakog } \\
\text { čovjeka na životu; ljudska populacija spada na šačicu ljudi koji žive } \\
\text { u stalnom strahu i oprezu. } \\
\text { OPIS IDENTITETA LIKA (8): djeca iz tradicionalne židovske obi- } \\
\text { telji; devetogodišnja djevojčica; umirovljen; dijete sa sela; umjet- } \\
\text { nički genij; zreli čovjek s raznim nedaćama; likovi iz mitologije ili } \\
\text { su povezani s njom; židovski mladić. } \\
\text { OPIS RAZVOJA LIKA (7): mentalni i fizički razvoj lika; prilagod- } \\
\text { ba okolini, tolerancija, želja za promjenom... sve je to moguće ako } \\
\text { čovjek odluči; prati cijeli život junaka; prati djecu koja odrastaju; } \\
\text { nepromjenjivost ljudskog karaktera; odrastanje; sazrijevanje ljubavi. } \\
\text { OPIS AKTIVNOSTI LIKA (6): prvenstveno govori kroz misli } \\
\text { drugih likova; vodi buran život; smiješno i simpatično, naporno i } \\
\text { izluđujuće ponašanje; bitka sa samim sobom; nemogućnost lika da } \\
\text { se dalje bori; dati će sve od sebe da stvari ponovno dovede u red. } \\
\text { OPIS NAČINA KARAKTERIZACIJE (4): brutalno ogoljen čo- } \\
\text { vjek; jedan je narod prikazan u svom pravom licu, sa svim svojim } \\
\text { manama i dobrim stranama; čovjek prikazan bez uljepšavanja i kli- } \\
\text { šeja; nema karakterizacije; OPIS BROJA LIKOVA (4): priča dvoje } \\
\text { ljubavnika-mrzitelja; kroz priču upoznajemo pet nepovezanih li- } \\
\text { kova; tri dijela i svaki dio ima lika na kojem je fokus; puno likova } \\
\text { ČITATELJ SE POISTOVJEĆUJE S LIKOM (1): dojam da se na- } \\
\text { lazimo u koži lika }\end{array}$ \\
\hline
\end{tabular}




\begin{tabular}{|c|c|}
\hline $\begin{array}{c}\text { Kategorije } \\
\text { privlačnosti knjige }\end{array}$ & Izrazi i potkategorije za opis privlačnosti knjige \\
\hline $\begin{array}{c}\text { Ukupno } 32 \text { izraza podi- } \\
\text { jeljena u šest potkate- } \\
\text { gorija. }\end{array}$ & $\begin{array}{l}\text { RADNJA USMJERENA NA LIKOVE (9 izraza): priča dvoje lju- } \\
\text { bavnika-mrzitelja; prati dosadan život nekoliko ljudi i njihov po- } \\
\text { gled na taj život; prati cijeli život junaka; prati djecu koja odrastaju; } \\
\text { život djevojčice s novim roditeljima; detaljan prikaz života lika; } \\
\text { nepromjenjivost ljudskog karaktera; bitka sa samim sobom; odra- } \\
\text { stanje. } \\
\text { RADNJA USMJERENA NA UŽE DEFINIRANA VANJSKA } \\
\text { ZBIVANJA (7): život u Zagrebu i Turopolju; dolazak bijelog čo- } \\
\text { vjeka u Afriku; priče afričkog naroda; afričke uzrečice i običaji; } \\
\text { klupska, queer scena; droga i seks; stvarnost života u totalitarnom } \\
\text { SSSR-u. } \\
\text { RADNJA USMJERENA NA ŠIRE DEFINIRANA VANJSKA } \\
\text { ZBIVANJA (6): politička zbivanja; prikaz jednog naroda; borba } \\
\text { protiv struktura moći; puno akcije; političke i društvene promjene; } \\
\text { teški događaji. } \\
\text { RADNJA USMJERENAINALIKOVE INA VANJSKAZBIVAN- } \\
\text { JA (1): priča djevojčice u kaosu Drugog svjetskog rata. } \\
\underline{\text { RADNJA KAO IZRAZ AUTOROVE DRUŠTVENE KRITIKE }} \\
\text { (2): osuda hipokrizije ,božjih ljudi“; gotovo svaka priča je odraz } \\
\text { otuđenog društva; } \\
\text { OSTALO (7): ljubav okosnica, bit ove cijele tople priče; nema rad- } \\
\text { nje; ljubavna priča; odnos prošlosti i sadašnjosti; borba dobra i zla; } \\
\text { povijesno-ljubavna priča; sazrijevanje ljubavi. }\end{array}$ \\
\hline $\begin{array}{c}\text { Ukupno } 10 \text { izraza podi- } \\
\text { jeljenih u šest potkate- } \\
\text { gorija. }\end{array}$ & $\begin{array}{l}\text { OPISI UGODE ( } 2 \text { izraza): topla priča; ako vam treba nešto poetič- } \\
\text { no i mirno uz kišni dan. } \\
\text { OPISI NEUGODE (4): ovo je bila surova i - na trenutke - šokantna } \\
\text { vožnja; gotovo svaka priča odražava sliku društva koje će doći (ili } \\
\text { koje je već došlo), u kojem smo strašno otuđeni; nekako su sve pri- } \\
\text { če depresivne, sve završavaju u nekom tonu beznađa, smrti; teški } \\
\text { događaji. } \\
\text { OPISI UGODE I NEUGODE (1): nada i ljepota koje opstaju usred } \\
\text { užasa. } \\
\text { OPISI S VIŠKOM DETALJA (1): preopširni opisi. } \\
\text { NADREALNI OPISI (1): fantastični motivi. } \\
\text { OSTALO (1): lirski pasaži koji intenzivnošću vizualnih, akustič- } \\
\text { nih, olfaktivnih slika sinestezijski dočaravaju život norveškog kra- } \\
\text { ja, prije svega prirode. }\end{array}$ \\
\hline
\end{tabular}




\begin{tabular}{|c|c|}
\hline $\begin{array}{c}\text { Kategorije } \\
\text { privlačnosti knjige }\end{array}$ & Izrazi i potkategorije za opis privlačnosti knjige \\
\hline $\begin{array}{l}\text { Ukupno } 52 \text { izraza po- } \\
\text { dijeljena u } 13 \text { potkate- } \\
\text { gorija. }\end{array}$ & $\begin{array}{l}\text { REALISTIČNO (1 izraz): realan prikaz života. } \\
\text { UMJERENO (7): nema spektakularnosti; nema bombastičnosti; } \\
\text { nepretenciozno; pristojno; bez uljepšavanja; bez pretjerivanja; bez } \\
\text { grubih riječi. } \\
\text { PROVOKATIVNO (3): šokantno; provokativno; polemičnost. } \\
\text { JEDNOSTAVNO (5): nije duboko; pitka proza; jasno i nedvosmi- } \\
\text { sleno; jednostavno; jasno. } \\
\text { SLOŽENO (5): kompleksno; filozofska pitanja; slojevitost; mo- } \\
\text { gućnost višestrukog išcitavanja rečenica; ne prolazi se lako kroz } \\
\text { djelo. } \\
\text { SLIKOVITO (5); vizualne, akustične, olfaktivne slike; sinestezij- } \\
\text { ski; žive slike; slike pune boja; slikovito. } \\
\text { METAFORIČNO (3): metafore; preneseno značenje; simboličnost. } \\
\text { EKSPERIMENTALNO (2): eksperimentalna knjiga modernizma; } \\
\text { istražuje snagu riječi. } \\
\text { IZNENAĐUJUĆE (3): iznenađujuć kraj; neizvjesno do kraja; an- } \\
\text { tiklimaktičnost. } \\
\text { NADAHNUTO (5): vješto osvježeni već izlizani motivi; do izra- } \\
\text { žaja dolazi ljepota jezika; zanimljivi obrati; uzbudljiva fabula; kre- } \\
\text { ativno. } \\
\text { NENADAHNUTO (5): naracijski problemi; predvidljivo; razoča- } \\
\text { ravajući završetci; preizravno; zamjerka što su neuredni dijalozi. } \\
\text { UGOĐAJNO (6): ironično; naivno; zabavno; bajkovito; melanko- } \\
\text { lično; crna parodija. } \\
\text { OSTALO (2): drugačije od suvremenika; avanturističko. }\end{array}$ \\
\hline
\end{tabular}

U tablici 2 vidimo da je u prikazima pronađeno najviše izraza koji opisuju stil (53 izraza), karakterizaciju (51) i usmjerenost radnje (32), dok je znatno manje izraza koji opisuju okvir i ton (10) te brzinu razvoja radnje (7). Što se tiče potkategorija pojedine kategorije privlačnosti radnje, najviše je potkategorija definirano za kategoriju stil (13 potkategorija), potom za kategorije karakterizacija (7 potkategorija), usmjerenost radnje (6), okvir i ton (6), brzina razvoja radnje (2). U tablici 2 može se uočiti da je za prvu kategoriju privlačnosti knjige - brzinu razvoja radnje - u prikazima pronađeno ukupno sedam izraza koji su svrstani u dvije potkategorije. Od sedam izraza za određivanje brzine razvoja radnje, čak se četiri izraza odnose na određivanje brzine početnog dijela radnje: spor početak; dug uvod; dosadan početak; brzo počinje zaplet, stoga je za te izraze definirana potkategorija: brzina razvoja početka radnje. Ukupno 51 izraz za opis karakterizacije podijeljen je u sedam potkategorija, od kojih je uvjerljivo najbrojnija potkategorija opis osobine lika s ukupno 21 izraza. U tu su kategoriju uvršteni izrazi iz kojih je vidljiva određena osobina lika, npr. strpljiv i brižan; misteriozan lik; 
dobrodušan. Pojedine od definiranih potkategorija mogle bi se po potrebi dalje granati u nove potkategorije, posebno one potkategorije koje sadrže puno izraza za opis privlačnosti knjige poput potkategorije opis osobina lika. Nešto manje izraza, njih 8, sadrži potkategorija opis identiteta lika u koju su uvršteni izrazi iz kojih je vidljiva bitna odrednica identiteta lika, npr. odrednica mjesta življenja u izrazu dijete sa sela ili odrednica dobi u izrazu devetogodišnja djevojčica. U potkategoriji opis razvoja lika nalazimo sedam izraza; ta potkategorija sadrži izraze koji opisuju razvoj, sazrijevanje i odrastanje likova, a uvršten je i sljedeći izraz koji ukazuje na nepromjenjivost lika: nepromjenjivost ljudskog karaktera, s obzirom na to da ukazuje na nemogućnost razvoja. Za takve bi se izraze možda mogla napraviti dodatna potkategorija. Definiranje tih potkategorija zacijelo nije apsolutno objektivan postupak, iako treba nastojati da se uspostave što jasniji kriteriji za definiranje potkategorija. Stoga su one zasigurno podložne reviziji, tj. promjenama i nadogradnjama s obzirom na različite potrebe, ciljeve i kriterije njihovih stvaratelja i korisnika. U ovome radu predstavljena je jedna mogućnost potkategorizacije pronađenih izraza privlačnosti knjige za koju smo nastojali da bude što jasnija i utemeljenija.

U tablici 2 nalaze se i podaci o izrazima i potkategorijama kategorije usmjerenosti radnje. Ukupno 32 izraza iz te kategorije podijeljena su u šest potkategorija, među kojima je najbrojnija potkategorija radnja usmjerena na likove koja uključuje izraze poput: prati cijeli život junaka; detaljan prikaz života lika; odrastanje. Izrazi u toj potkategoriji ukazuju na to da je fokus radnje recenzirane knjige usmjeren na likove. Vrijedi primijetiti da bi se više izraza iz te potkategorije moglo ujedno uvrstiti i u prethodno opisanu potkategoriju opis razvoja lika koja se nalazi u kategoriji karakterizacija. Naprimjer izraz odrastanje, koji upućuje na to da je radnja knjige fokusirana na odrastanje lika, ujedno podrazumijeva i razvoj lika, jer nema odrastanja bez psihofizičkog razvoja, te bi se stoga ovaj izraz mogao svrstati i u potkategoriju opis razvoja lika. Stoga je bitno imati na umu da kod kategorizacije i potkategorizacije pronađenih izraza za opis privlačnosti knjige nije rijedak slučaj da se isti izrazi mogu istodobno svrstati u više kategorija i potkategorija.

U kategoriji usmjerenosti radnje opisat ćemo još dvije potkategorije koje sadrže donekle sadržajno slične izraze, ali smo ipak među njima pronašli jasnu razlikovnu nit te ih stoga odijelili u dvije različite potkategorije. Prva je potkategorija s nazivom radnja usmjerena na uže definirana vanjska zbivanja te sadrži sedam izraza, među kojima: život u Zagrebu i Turopolju; priče afričkog naroda; klupska, queer scena. U njoj su izrazi koji upućuju na to da se u knjizi prikazuju vanjska zbivanja, dakle ne zbivanja u svijesti osobe, već u okolini koja okružuje osobe. Također ta potkategorija sadrži izraze koji upućuju na konkretne okoline ili zajednice u kojima se odvija to zbivanje, npr. Zagreb, Turopolje, queer scena. Druga je potkategorija s nazivom radnja usmjerena na šire definirana vanjska zbivanja te sadrži šest izraza, među kojima: politička zbivanja; borba protiv struktura moći; 
puno akcije. U njoj su izrazi koji upućuju na to da se u knjizi prikazuju vanjska zbivanja, ali se u izrazima ne naznačuje konkretna okolina ili zajednica u kojoj se odvijaju ta zbivanja.

U tablici 2 nalaze se također podaci o izrazima i potkategorijama kategorije okvir i ton. Ukupno deset izraza iz te kategorije podijeljeno je u šest potkategorija, među kojima je najbrojnija potkategorija opisi neugode koja uključuje izraze poput: gotovo svaka priča odražava sliku društva koje će doći (ili koje je već došlo), u kojem smo strašno otuđeni; nekako su sve priče depresivne, sve završavaju u nekom tonu beznađa, smrti. Kako to govori i samo ime potkategorije, izrazi u njoj opisuju događanja što uzrokuju neugodne doživljaje. S druge strane, u prikazima su pronađeni i izrazi koji opisuju događanja što uzrokuju ugodne doživljaje te su svrstana u potkategoriju opisi ugode. Radi se o sljedeća dva izraza: topla priča; ako vam treba nešto poetično i mirno uz kišni dan.

Na kraju tablice 2 nalaze se podaci o izrazima i potkategorijama kategorije stil. U ovoj izrazima najbrojnijoj kategoriji (52 izraza) postoji i najveći broj potkategorija, njih čak 13. Vrijedi nabrojati ove vrlo raznovrsne potkategorije: realistično, umjereno, provokativno, jednostavno, složeno, slikovito, metaforično, eksperimentalno, iznenađujuće, nadahnuto, nenadahnuto, ugođajno, ostalo. Ukratko ćemo opisati nekoliko navedenih potkategorija. Potkategorija umjereno sadrži sedam izraza koji opisuju umjerenost u načinu pisanja knjige. Ovo su primjeri pojedinih izraza: nema bombastičnosti, bez uljepšavanja, bez grubih riječi. Dakle radi se o opisu spisateljske umjerenosti na raznim planovima: od umjerenosti u opisima (bez uljepšavanja) do umjerenosti u komunikaciji (bez grubih riječi). Potkategorija provokativno sadrži izraze koji su svojevrsna suprotnost izrazima koje sadrži potkategorija umjereno. Ovo su primjeri pojedinih izraza: šokantno, polemičnost. Naprimjer u ovu potkategoriju uvrstili smo izraz polemičnost jer bilo koja polemika neizostavno uključuje provokaciju. Suprotstavljeni polemičari svojim suprotstavljenim stavovima provociraju suprotnu stranu na odgovor i pobijanje izrečenoga. U slučaju knjiga, može se raditi o polemici likova u knjizi, ali se može raditi i o polemici koju autor knjige svojim tekstom upućuje čitatelju ili određenoj zajednici. Potkategorija nadahnuto sadrži izraze koji ukazuju na umijeće i talent pisaca knjige, naprimjer hvaleći pojedine uspješne dijelove knjige. Ovo su primjeri pojedinih izraza: do izražaja dolazi ljepota jezika; zanimljivi obrati; uzbudljiva fabula. S druge strane, izrazi suprotnog značenja nalaze se u potkategoriji nenadahnuto. Izrazi koji ukazuju na neuspješne, nenadahnute knjige ili njihove dijelove jesu naprimjer: predvidljivo, preizravno, naracijski problemi. $\mathrm{Na}$ kraju, opisat ćemo potkategoriju ponešto neobičnog naziva: ugođajno. Naziv je dobila zato što sadrži izraze koji opisuju ugođaj koji pisac svojim stilom stvara u knjizi. Naprimjer to su izrazi: bajkovito; melankolično, ironično. U tu potkategoriju uključen je i izraz crna parodija koji, osim što ukazuje na ugođaj knjige, ujedno ukazuje i na žanr knjige. 


\section{Rasprava}

U prvom su dijelu istraživanja anketom dobiveni rezultati o različitim aspektima korištenja portala Goodreads. Dio anketnih pitanja bio je usmjeren na istraživanje usluge savjetovanja čitatelja koju korisnici Goodreadsa pružaju jedni drugima. Odgovori ukazuju na to da ispitanici iz Hrvatske u prikazima koje pišu pružaju preporuke o čitanju. Također je utvrđeno da ispitanicima Goodreads služi i kao alat za stvaranje vlastitih evidencija knjiga te kao mjesto na kojem mogu dobiti savjete za odabir novih naslova za čitanje. Naprimjer jedan od ispitanika izjavljuje da mu je najkorisnije „to što lagano i pregledno mogu naći gotovo svaku knjigu koja postoji i dobiti osnovne informacije o toj knjizi (autor, godina izdanja, sadržaj...), kao i ocjenu i komentare drugih čitatelja što bude vrlo korisno kada ne mogu odlučiti želim li pročitati neku knjigu ili ne." Anketni odgovori ukazuju na to da ispitanici prikaze knjiga drugih korisnika Goodreadsa smatraju važnima za svoj proces odlučivanja o knjigama koje će čitati, ali i da sami spremno nude savjete drugim korisnicima. S obzirom na ove rezultate, vrijedi razmotriti mogućnosti i načine da se ove funkcionalnosti Goodreadsa prenesu u druga mrežna okruženja povezana s knjigama, npr. na knjižnične mrežne stranice.

U drugom je dijelu istraživanja provedena analiza sadržaja odabranih prikaza knjiga na Goodreadsu. Iz rezultata analize vidljivo je da su sve kategorije za opis privlačnosti knjige, prema Joyce Saricks, zastupljene u prikazima koje pišu korisnici Goodreadsa. Uočeno je da korisnici, za koje se može pretpostaviti da nisu profesionalci u pisanju prikaza, u svojem jeziku za opis knjiga koriste izraze koji bi se mogli smjestiti u kontekst savjetodavnog rada knjižnica. Može se reći da se autori analiziranih prikaza dobro snalaze u korištenju i razumijevanju rječnika privlačnosti knjiga. Osim toga, čitatelji i pisci prikaza na Goodreadsu u prikazima knjiga koriste i prepoznaju izraze kojima je svrha iskazivanje privlačnosti knjige. Naprimjer to potvrđuje jedan od ispitanika koji je u anketi na pitanje o razlozima objavljivanja prikaza na Goodreadsu izjavio: ,volim izdvojiti neke citate za koje smatram da daju dobar uvid u samo djelo (stil, ton, teme, itd.)“. Time ispitanik izravno potvrđuje svijest o tome da postoje određene kategorije prema kojima čitatelj može vrednovati književno djelo u odnosu na vlastite preferencije i unutar kojih se djelo može opisati. Uočeno je i da sve kategorije koje je predložila Saricks, prema brojnosti zastupljenih izraza, nisu jednako zastupljene u korisničkim prikazima knjiga. Ponajviše se po brojnosti izraza, uz kategoriju usmjerenosti radnje, ističu kategorije karakterizacija i stil. Stoga se može pretpostaviti kako su ti elementi autorima prikaza prilično važni kod odabira i uživanja u knjigama.

Rezultati upućuju na to da se autori analiziranih izraza dobro snalaze u izražavanju različitih aspekata privlačnosti knjiga. Izrazi koje pritom koriste mogu obogatiti zapis u knjižničnom katalogu, jer se njima dodaju informacije koje čitatelji nalaze korisnima u procesu odlučivanja o tome bi li neka knjiga mogla odgovarati njihovu ukusu ili ne. Osim toga, Caplinger ističe da dodavanje podataka o 
privlačnosti knjige u njezin kataložni zapis može omogućiti pretraživanje kataložnih zapisa prema privlačnosti ${ }^{82}$ Tada bi se izrazi privlačnosti u kataložnom zapisu mogli povezati, čime bi se pretraživanje proširilo te bi se korisnicima olakšao odabir novih knjiga za čitanje. Pritom treba voditi računa i o tome da izrazi privlačnosti kojima čitatelji opisuju knjige zbog utjecaja subjektivnosti mogu ponekad biti i zbunjujući ili nepouzdani. No bez obzira na potencijalne nedostatke ovog pristupa, vrijedi detaljnije istražiti njegove potencijalne prednosti, npr. može li i na koji način tako ‘obogaćen' kataložni zapis, prikaz knjige ili razgovor knjižničara s korisnikom unaprijediti korisničko iskustvo. Naprimjer knjižničari koji korisnicima savjetuju što čitati mogu razmotriti mogućnosti unapređivanja svoje aktivnosti tako da korisnicima pružaju čitalačke savjete oblikovane na temelju kategorija privlačnosti knjige koje je navela Joyce Saricks. U ovom istraživanju potvrđeno je da se čitatelji izrazima iz tih kategorija često služe u svojim opisima knjiga. Popis tih izraza, tj. rječnik privlačnosti, knjižničarima može pružiti dodatne smjernice $i$ inspiraciju u njihovim aktivnostima savjetovanja čitanja. Osim u razgovorima s korisnicima, izraze iz rječnika privlačnosti knjižničari mogu koristiti i u neizravnim oblicima savjetovanja, npr. kod izrade popisa knjiga prema određenoj kategoriji, poput popisa knjiga kojima je ton mračan i sumoran ili popisa knjiga koje su više usmjerene na likove nego na radnju. Prepoznavanje izraza i kategorija privlačnosti te grupiranje knjiga koje dijele određena slična obilježja s obzirom na te kategorije može unaprijediti savjetodavni rad knjižničara.

\section{Zaključak}

Svrha je ovoga rada pružanje doprinosa boljem razumijevanju savjetovanja čitatelja u digitalnom okruženju na primjeru portala Goodreads, ujedno i društvene mreže fokusirane na knjige i čitanje. Aktivnosti savjetovanja čitanja u knjižnicama i drugim ustanovama mogu se unaprijediti na temelju poznavanja rada ovog portala na kojemu se svakodnevno odvija mnoštvo različitih aktivnosti vezanih uz knjige i čitanje i na kojemu se stvara obilje sadržaja važnih za čitanje i čitalačku kulturu. Portal Goodreads koristi mnogo ljudi iz cijeloga svijeta, a na njemu podatke o knjigama čita i stvara mnogo korisnika iz Hrvatske, što je vidljivo i po postojanju Goodreads-grupe s nazivom CROATIA/grupa za čitatelje iz Hrvatske $i$ na hrvatskom jeziku. U provedenom istraživanju utvrđeno je da su korisnici Goodreadsa iz te grupe vrlo zadovoljni mogućnostima koje im nudi Goodreads te stoga nije neobično što većina njih, osim što čita prikaze drugih korisnika Goodreadsa, ujedno i piše svoje prikaze knjiga. Proučavanjem sadržaja i korisničkih aktivnosti Gooodreadsa, proučavanjem funkcionalnosti i sučelja koje Goodreads pruža korisnicima, djelatnici knjižnica, ali i drugih kulturno-baštinskih ustanova, mogu dobiti različite ideje za uspostavljanje novih usluga i nadograđivanje

82 Usp. Caplinger, V. A. Nav. dj., str. 290. 
već postojećih kako bi se te ustanove dodatno približile korisnicima, promovirale čitanje i sudjelovanje svojih korisnika u čitalačkim aktivnostima. Istraživanjem Goodreadsa i sličnih portala mogu se dobiti uvidi korisni za razvoj knjižnica u različitim aspektima: od unapređenja pristupa izgradnji zbirki i fonda, boljeg razumijevanja i provedbe savjetovanja čitatelja, prezentacije fonda korisnicima i uključivanja korisnika u aktivnosti knjižnice pa do ponude informativnijih sadržaja i veće vidljivosti knjižnice u zajednici. Mogućnosti unapređenja navedenih knjižničnih aktivnosti na temelju uvida u djelovanje portala i čitateljskih društvenih mreža poput Goodreadsa plodan su izvor tema za buduća istraživanja.

\section{LITERATURA}

Adkins, D.; J. S. Bossaller; Sandy, H. M. Exploring reader-generated language to describe multicultural literature. // The International Journal of Information, Diversity, \& Inclusion (IJIDI) 3, 2(2019), 1-20. [citirano: 2019-10-21]. Dostupno na: https://jps. library.utoronto.ca/index.php/ijidi/article/view/32591.

Amazon purchase of Goodreads stuns book industry. [citirano: 2019-8-11]. Dostupno na: https:/www.theguardian.com/books/2013/apr/02/amazon-purchase-goodreads-stuns-book-industry.

Anwyll, R.; B. Chawner. Social media and readers' advisory: a win-win combination? // Reference \& User Services Quarterly 53, 1(2013), 18-22. [citirano: 2019-10-21]. Dostupno na: https://go.galegroup.com/ps/anonymous?id=GALE\%7CA351948534.

Boot, P. The desirability of a corpus of online book responses. // Proceedings of the Second Workshop on Computational Linguistics for Literature / ed. by David Elson, Anna Kazantseva and Stan Szpakowicz, Stroudsburg, USA: The Association for Computational Linguistics, 2013. Str. 32-40. [citirano: 2019-10-01]. Dostupno na: https://dh2017.adho.org/abstracts/208/208.pdf.

Boot, P. A Database of online book response and the nature of the literary thriller. // Conference: Digital Humanities 2017, Montreal, Canada. [citirano: 2019-10-01]. Dostupno na: https://dh2017.adho.org/abstracts/208/208.pdf.

Burke, S. K.; M. Strothmann. Adult readers' advisory services through public library websites. // Reference \& User Services Quarterly 55, 2(2015), 132-143. [citirano: 2019-10-21]. Dostupno na: https://journals.ala.org/index.php/rusq/article/ view/5861.

Caplinger, V. A. In the eye of the beholder: readers' advisory from a cataloging perspective. // Reference \& User Services Quarterly 52, 4(2013), 287-290. [citirano: 2019-10-21]. Dostupno na: https://search.proquest.com/openview/a013e4b$90992804 \mathrm{c} 861 \mathrm{~b} 369 \mathrm{e} 443587 \mathrm{fc} / 1$. 
Collection development and evaluation section (CODES) Readers' advisory committee. Recommended readers' advisory tools. // Reference \& User Services Quarterly 43, 4(2004), 294-305. [citirano: 2019-10-21]. Dostupno na: https://www.jstor.org/stable/20864241.

Cordón-García, J. A.; J. Alonso-Arévalo; R. Gómez-Díaz; D. Linder. Social reading: platforms, applications, clouds and tags. Cambridge: Woodhead Publishing Limited, 2013.

Dali, K. From book appeal to reading appeal: redefining the concept of appeal in readers' advisory. // The Library Quarterly: Information, Community, Policy 84, 1(2014), 2248. Dostupno na: https://www.journals.uchicago.edu/doi/abs/10.1086/674034.

Goodreads. About us. [citirano: 2018-8-11]. Dostupno na: https://www.goodreads.com/ about/us.

Goodreads: CROATIA/grupa za čitatelje iz Hrvatske i na hrvatskom jeziku. [citirano: 2019-8-11]. Dostupno na: https://www.goodreads.com/group/show/2075-croatiagrupa-za-itatelje-iz-hrvatske-i-na-hrvatskom-jeziku.

Lockley, L. M.; L. Tarulli. All for one, one for all. // Reference \& User Services Quarterly 52, 2(2012), 98-101. [citirano: 2019-10-21]. Dostupno na: https://www.jstor.org/ stable/pdf/refuseserq.52.2.98.pdf.

Moyer, J. Research-based readers' advisory. Chicago: American Library Association, 2008.

Naik, Y. Finding good reads on Goodreads: readers take RA into their own hands. // Readers' Advisory, 51, 4(2012), 319-323. [citirano: 2019-10-21]. Dostupno na: https:// search.proquest.com/openview/13af6aa2927cf99374c6366467f65bdf/1.

NoveList. [citirano: 2019-10-02]. Dostupno na: https://www.ebscohost.com/novelist.

NoveList's Story Elements. [citirano: 2019-10-02]. Dostupno na: https://www.ebscohost.com/novelist/idea-center/learn/learn-story-elements.

Šauperl, A. Pinning down a novel: characteristics of literary works as perceived by readers. // Library review 61. 4(2012), 286-303. [citirano: 2019-10-21]. Dostupno na: https://www.emerald.com/insight/content/doi/10.1108/00242531211267581/full/ html.

Saricks, J. G. Readers' advisory service in the public library. Chicago: American Library Association, 2005.

Smith, D. Talking with readers: a competency based approach to readers' advisory service. // Reference \& User Services Quarterly 40, 2(2000), 135-142. [citirano: 2019-10-21]. Dostupno na: https://search.proquest.com/openview/962dd40e6c6da$1853649753 \mathrm{~b} 99 \mathrm{~d} 1 \mathrm{f} 668 / 1$.

Spiteri, L.; J. Pecoskie. Expanding the scope of affect: taxonomy construction for emotions, tones, and associations. // Journal of Documentation 74, 2(2018), 383-397. 
[citirano: 2019-10-21]. Dostupno na: https://www.emerald.com/insight/content/ doi/10.1108/JD-02-2017-0026/full/html.

Stover, K. M. Stalking the wild appeal factor: readers' advisory and social networking sites. // Reference \& User Services Quarterly 48, 3(2009), 243-269. [citirano: 201910-21]. Dostupno na: https://search.proquest.com/openview/651d473641c4fab2bbf2754ac9b782b8/1.

Trott, B. Advising readers online: a look at internet-based reading recommendation services. // Reference \& User Services Quarterly 44, 3(2005), 210-215. [citirano: 201910-21]. Dostupno na: https://www.jstor.org/stable/20864364.

Ward, M.; J. Saarti. Reviewing, Rebutting, and Reimagining Fiction Classification. // Cataloging \& Classification Quarterly 56, 4(2018), 1-13. [citirano: 2019-10-21]. Dostupno na: https://www.tandfonline.com/doi/abs/10.1080/01639374.2017.14114 14. 